\title{
THE VERTICAL SEPARATION OF POWERS
}

\author{
VICTORIA NOURSE $\dagger$
}

\begin{abstract}
Standard understandings of the separation of powers begin with the concept of function. Professor Nourse argues that function alone cannot predict important changes in structural incentives and thus serves as a poor proxy for assessing real risks to governmental structure. To illustrate this point, the Article returns to proposals considered at the Constitutional Convention and considers difficult contemporary cases such as Morrison v. Olson, Clinton v. Jones, and the Supreme Court's more recent federalism decisions. In each instance, function appears to steer us wrong because it fails to understand separation of powers questions as ones of structural incentive and political relationship. In order to move away from function as the sole proxy for structural risk, the Article suggests a "vertical" approach toward separation of powers questions. That approach reconceives departmental power less as the power to perform a set of tasks fitting a particular constitutional description (e.g., adjudication, execution, legislation) than as a set of constitutionally created political relationships between the people and those who govern them. Put another way, the separation of powers becomes less a search for transcendental descriptions of the departments than a means of considering how shifting structure affects liberty-how structural incentives may incline governmental actors to act toward the people in ways that risk the electoral powers of both majorities and minorities.
\end{abstract}

$\dagger$ Victoria Nourse, Associate Professor of Law, University of Wisconsin. Special thanks to Ann Althouse, Neil Komesar, and Jane Schacter for reading early drafts of this Article, as well as to the members of the Columbia Legal Theory Workshop and, in particular, to Michael Dorf, George Fletcher, and Peter Strauss for listening to the some of the ideas presented in an early version of this Article. I would also like to thank the students in Professor Komesar's Law and Economics seminar, who read and commented on a later draft. The editors of the Duke Law Journal, in particular Scott Thompson, provided excellent assistance. All errors are, of course, my own. 


\section{TABLE OF CONTENTS}

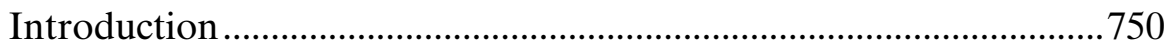

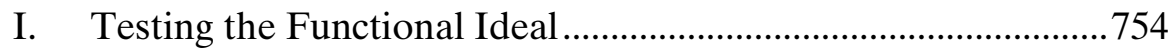

A. A Vertical Challenge ......................................................... 757

B. A Hypothetical Constitution ..............................................760

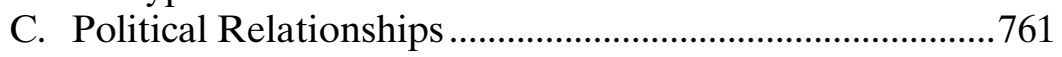

II. Bridging the Realism Gap ........................................................... 768

A. Can a Man "Happen" to Be President? ..............................768

B. Morrison v. Olson: Will Congress's Role Please Step

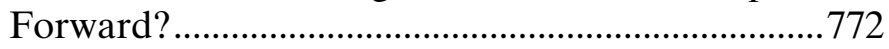

C. The Federalism Cases: At the Intersection of

Horizontal and Vertical Separation .......................777

III. Considering Political Relationships............................................. 781

A. Structure and Constituent Harms ....................................... 781

B. Shifting Constituencies: The Comparative Nature of Vertical Analysis.....................................................784

C. The Silent Demands of the Functional Ideal .....................788

D. The Counterarguments .......................................................795

IV. The Idea of Power and the Courts' Role in Separation of Powers Cases .....

\section{INTRODUCTION}

Tell a lawyer to take out a pen and paper and to write down the power the Constitution provides to the Congress, the President, and the courts. No doubt she will provide you with something that looks vaguely like the Vesting Clauses ${ }^{1}$ or a list of governmental functions, emphasizing the executive, legislative, and judicial. What you will not have is a working government-or at least, there will be no one running it, no one voting for it, and no one representing anyone else. You may excise the words "executive," "legislative," and "judicial" from the Vesting Clauses, replace them with other adjectives, or strike the Vesting Clauses altogether. ${ }^{2}$ People will still vote, ${ }^{3}$ Congress will still

1. See U.S. CONST. art. I, § 1 ("All legislative Powers herein granted shall be vested in a Congress of the United States ....”); id. art. II, § 1, cl. 1 ("The executive Power shall be vested in a President of the United States of America."); id. art. III, § 1 ("The judicial Power of the United States, shall be vested in one supreme Court, and in such inferior Courts as the Congress may from time to time ordain and establish.").

2. By "Vesting Clauses," I mean the specific language in the first sentences of the provisions of Article I, Section 1; Article II, Section 1; and Article III, Section 1 of the Constitution. See supra note 1 (quoting the relevant language).

3. The Vesting Clauses do not create the electoral relationships contemplated by the Con- 
convene, ${ }^{4}$ the Supreme Court will still decide cases, ${ }^{5}$ and the President will still direct his administration. ${ }^{6}$ The Constitution describes our government as a compendium of executive, legislative, and judicial powers, ${ }^{7}$ but it also creates that government by constituting electoral relationships that confer political authority. ${ }^{8}$

If this is right, then it is time to reconsider a basic assumption relied upon by scholars, courts, and lawyers in analyzing separation of powers controversies. It is a commonplace of structural theory that we have three branches of government arranged horizontally along "functional" lines, separating judicial from executive from legislative power. In this Article, I urge that this image of horizontal separation is incomplete if it does not take into account the "vertical" ${ }^{10}$ aspects of

stitution. See U.S. CONST. art. I, §§ 2-3 (establishing the process by which members of the House of Representatives and the Senate are elected); id. art. II, § 1, cls. 2-3 \& amend. XII (creating the process by which Presidents are elected); $i d$. amend. XVII (providing for the direct election of Senators).

4. Outside the Vesting Clauses, the Constitution specifies that "[t]he Congress shall assemble at least once in every Year." Id. art. I, § 4, cl. 2.

5. Article III, Section 1 of the Constitution provides for the appointment of Supreme Court "judges" and their payment and tenure in a sentence separate from the Vesting Clause. Even if one were to strike the first sentence of Article I "vesting" judicial power, section 2 would still provide for the "Judicial Power" and specify that it "extend[s] to all cases in Law and Equity ...." Id. art. III, $\S 2$.

6. See U.S. ConST. art. II, $\S 1$, cls. $2-3 \&$ amend. XII (providing for the election of the President); $i d$. art. II, $\S 2$, cl. 2 (authorizing the President's appointment of executive officers); $i d$. art. II, $\S 3$ (establishing the President's duty to faithfully execute the laws).

7. See supra note 1 (referring to the Vesting Clauses and the "legislative," "executive," and "judicial" powers of the federal government).

8. See U.S. CONST. art. I, $\S 2$ (providing for the election of members of the House of Representatives); id. art. I, §3, cl. $1 \&$ amend. XVII (establishing a process for the election of members of the Senate); id. art. II, $\S 1$, cls. 2-3 (creating procedures for the election of the President); $i d$. art. II, § 2, cl. 2 (granting the President the power to nominate Justices to the Supreme Court)

9. I use the term "functional" throughout this Article to refer to the use of "function" to describe our three principal governmental bodies. It is not intended to refer to the school of thought known as functionalism. When I use the term "functional," it can describe either a formalist or a functionalist approach. See infra note 27. When, however, I use the terms "functionalist" or "functionalism," I am referring to a particular school of thought. Let me also emphasize that I am not saying that the descriptive terms in the Vesting Clauses are constitutionally irrelevant; they may be quite relevant in determining the limits on an individual institution's power. The question remains whether they are particularly helpful in assessing separation of powers questions.

10. I borrow this term from Justice Kennedy's recent concurring opinion in Clinton v. City of New York, 524 U.S. 417, 452 (1998) (Kennedy, J., concurring) (stating that the "[s]eparation of powers operates on a vertical axis as well, between each branch and the citizens in whose interest powers must be exercised"), although the notion that vertical relationship is important to political structure is quite old. See, e.g., HANNAH ARENDT, ON VIOLENCE 44 (1970) (discussing 
political power, aspects that are intimately connected with notions of constitutional risk and institutional incentive. By vertical power, I mean those relationships between government and constituency that create and, in this sense, constitute the three different branches of our government. ${ }^{11}$ The power created by our Constitution comes from more than constitutional description; it comes from the people, aggregated in different kinds of constituencies, commonly distinguished as districts, states, and nation. Thus, every shift in governmental function or task can be reconceived, not simply as a shift in tasks but also as a shift in the relative power of popular constituencies. For example, rather than asking whether a shift in power is really executive or legislative, we might ask from which constituency the power comes, and to which constituency it is given, and what relative risks and incentives that shift entails for those constituencies. The risk on which we would focus would not be the fuzziness of a functional label, but, instead, the risk that a shift in power would create substantial incentives for government actors to silence a majority or to oppress a minority. There may be no easy answers here; indeed, the calculus may be quite complex, but at the same time it may represent an "angle of vision" $"$ that is distinctly more realistic than much legal discussion on structural matters. Indeed, I believe that a vertical approach may lead us toward a functionalism that frees us from the standard battles about whether we really can define the legislative, the judicial, and the executive.

power as political relationship_-"being empowered by a certain number of people to act in their name"-in light of Madison's claim that power is public opinion); JEAN HAMPTON, POLITICAL PHILOSOPHY 105 (1997) (discussing the historical pedigree of the concept that the people grant political authority to their government); see also Victoria Nourse, Toward a "Due Foundation" for the Separation of Powers: The Federalist Papers as Political Narrative, 74 TEX. L. REV. 447 (1996) (discussing the appearance of this idea in The Federalist Papers).

11. A "constituency relationship" is one likely to create incentives to act in accordance with the power to elect, appoint, direct, or remove. By constituency relationships, I mean both direct and indirect relationships. Indeed, the absence of such relationships may form an important part of the incentive picture. Thus, for example, that the Supreme Court has no direct relationship to any electoral constituency means that it has different incentives than does the Congress, which has direct electoral relationships. All judgments about constituency relationships offered in this Article are comparative judgments about likely incentives. I make no claim that any of these relationships "work" in some abstract sense. Thus, even if one cannot say that the House of Representatives does a good job of representation, one can say that its electoral relationships are more local than those of the President. See Bruce ACKerman, We the People: FOUNDATIONS 69 (1991).

12. JAMES WILlARD HURST, LAW AND CONDITIONS OF FREEDOM 5 (1956). 
In Part I, I argue that the idea of function cannot predict important shifts in constitutional structure: I examine changes in structure that do not shift function but, nevertheless, clearly shift political power and important structural incentives. I argue that these shifts can best be explained in terms of vertical separation-that power may shift even when function has not because a shift in political relationship creates new structural incentives. In Part II, I urge that the vertical separation of powers may help us understand the "realism gap" between the nation's political life and the Supreme Court's recent and most controversial separation of powers cases: Clinton v. Jones ${ }^{13}$ and Morrison v. Olson. ${ }^{14} \mathrm{I}$ also address the impact of this analysis on the Court's even more recent federalism cases, arguing that federalism and separation of powers concerns intersect. In Part III, I flesh out the implications of this theory, including the concept of shifting structural risk upon which the theory depends. When political relationships change, political incentives change. When one political audience is replaced by another, political actors have new incentives to act in accordance with the interests of those who now grant or control their power. With those new incentives comes the possibility that some constituencies will gain at the expense of others. Put another way, shifting structural incentives creates risks that our form of government may change because government decisionmakers have new incentives to silence or privilege some constituencies, preferring the many at the expense of the few or the few at the expense of the many. ${ }^{15}$ In Part IV, I conclude by suggesting that, in failing to account for the vertical aspects of constitutional structure, lawyers have applied a view of political power that is an ideal of legal power. This yields a law of constitutional structure that is persistently repetitive, that is wooden, and ultimately, that challenges the "central principle

13. 520 U.S. 681 (1997).

14. 487 U.S. 654 (1988).

15. Although this focus on incentive and political relationship is not common among scholars, it is far from unknown to economists and others knowledgeable about institutions and economic theory. My notion of constitutional risk is based on modern-day institutional choice theory, which emphasizes a participation-centered, two-force model of politics based on majoritarian and minoritarian risk. See, e.g., NEIL K. KOMESAR, IMPERFECT ALTERNATIVES ch. 3 (1994); see also infra text accompanying notes 133-37 (discussing the concepts of majoritarian and minoritarian risk). This focus on incentives is also consistent, however, with more ancient discourses. See Cass R. Sunstein, Bad Incentives and Bad Institutions, 86 GEO. L.J. 2267, 2279 (1998) [hereinafter Sunstein, Bad Incentives] ("One of the great achievements of the Framers of the American Constitution was to link the analysis of institutions to an understanding of incentives."). 
of our legal order, that law exists for the benefit of people and not people for the benefit of law."16

\section{TESTING THE FUNCTIONAL IDEAL}

When lawyers and judges write about constitutional structure, they typically reach out to the terms "executive," "judicial," and "legislative" and seek to define and describe them, and thus to cabin them, as function. ${ }^{17}$ Soon, deciding separation of powers controversies becomes a question of squeezing new proposals-the legislative veto ${ }^{18}$ the line-item veto, ${ }^{19}$ the Sentencing Commission ${ }^{20}$-into old functional categories. Too often, however, the actual results disappoint. The Supreme Court openly quarrels about how to characterize a particular innovation, and when all the opinions are added up, we find that different members of the Court have described a single activity as executive, judicial, and legislative. ${ }^{21}$ Not surprisingly, scholars wax cynical and temporize, resorting in the end to repeating Justice Jackson's quotation about how it is all a hopeless mess of canceling quotations. ${ }^{22}$ Soon, students are left with the impression that one of the most important features of constitutional law-the structure of government-makes no sense and that all we can say in the end is

16. HURST, supra note 12 , at 5 .

17. Often this is done in reference to "traditional" functions. See, e.g., Martin H. Redish \& Elizabeth J. Cisar, "If Angels Were to Govern": The Need for Pragmatic Formalism in Separation of Powers Theory, 41 DUKE L.J. 449, 480 (1991) (arguing that the judicial branch should be confined to areas of "the "traditional' judicial function"). At other times, however, courts define these terms in more general ways. See, e.g., Bowsher v. Synar, 478 U.S. 714, 733 (1986) (defining "execution" as "exercis[ing] judgment concerning facts that affect" the law and "interpret[ing] the provisions" of the law).

18. See INS v. Chadha, 462 U.S. 919, 959 (1983) (invalidating the legislative veto).

19. See Clinton v. City of New York, 524 U.S. 417, 448 (1998) (determining that the Line Item Veto Act's cancellation provisions and authorized procedures violated the Constitution).

20. See Mistretta v. United States, 488 U.S. 361, 412 (1989) (holding that the use of the Sentencing Commission to set guidelines under the 1984 Sentencing Reform Act was not unconstitutional).

21. See, e.g., Chadha, 462 U.S. at 952 (1983) (describing the legislative veto as a legislative action affecting executive action); $i d$. at 960 (Powell, J., concurring) (describing implementation of the veto as adjudicative action); $i d$. at 1001 (White, J., dissenting) (describing the veto as a legislative exercise countermanding legislative action by an agency).

22. See, e.g., E. Donald Elliott, Why Our Separation of Powers Jurisprudence Is So Abysmal, 57 GeO. Wash. L. REv. 506, 525 (1989) (“'A century and a half of partisan debate and scholarly speculation yields no net result but only supplies more or less apt quotations from respected sources on each side of any question. They largely cancel each other." (quoting Youngstown Sheet \& Tube Co. v. Sawyer, 343 U.S. 579, 634-35 (1952) (Jackson, J., concurring))). 
that things are "a mess." 23 Yet, despite all the cynicism, when new controversies arise, these same students are taught by courts and scholars to return quite readily to the very intellectual process that has been branded as corrupt- the hope that we may cabin power by finding a unique departmental description. ${ }^{24}$

Conventional schools of thought about the separation of powers have done little to challenge and much to entrench the technocratic vision that comes with seeing the departments ${ }^{25}$ as function. So-called formal approaches to the separation of powers, for example, insist that it is possible to achieve departmental separation if we simply hew to a sufficiently rigid tripartite formula. ${ }^{26}$ Functional unity, we are told, will keep the departments separate; as long as executive powers

23. DANiel A. FARber et Al., CASES AND MAterial on CONSTitutional Law: THEMES FOR THE CONSTITUTION'S THIRD CENTURY 1024 (1993) (admonishing students that "[t]he Supreme Court's treatment of separation of powers issues ... is ... a "mess" "and that academic theories have flourished because the "Court seems unsure of what to do ...." (citing Stephen L. Carter, Comment, The Independent Counsel Mess, 102 HARV. L. REV. 105 (1988))).

24. Indeed, "function-talk" appears in a variety of otherwise diverse scholarship on the separation of powers. See, e.g., Rebecca L. Brown, Separated Powers and Ordered Liberty, 139 U. PA. L. REV. 1513 (1991) (arguing that separation of powers disputes involve important questions of individual rights); Abner S. Greene, Checks and Balances in an Era of Presidential Lawmaking, 61 U. CHI. L. REV. 123 (1994) (emphasizing the checks and balances between the President and Congress); Harold J. Krent, Separating the Strands in Separation of Powers Controversies, 74 VA. L. REV. 1253, 1256 (1988) (arguing that "the Constitution circumscribes the power of the branches by limiting the ways each can act"); Peter L. Strauss, Formal and Functional Approaches to Separation-of-Powers Questions-A Foolish Inconsistency?, 72 CORNELL L. REV. 488, 522 (1987) ("[C]ourts should view separation-of-powers cases in terms of the impact of challenged arrangements on the balance of power among the three named heads of American government"); Paul R. Verkuil, Separation of Powers, The Rule of Law and the Idea of Independence, 30 WM. \& MARY L. REV. 301 passim (1989) (emphasizing a rule of law approach that minimizes conflicts of interest).

25. My usage of the term "department" to denote the three main governmental bodiesPresident, Supreme Court, and Congress—might seem odd. Conventional modern usage speaks of the courts, Congress, and the President as "branches." As Madison explained, the Framers often referred to the three main bodies as "departments." One of the departments, the Congress, has two branches, namely the House and the Senate. See THE FEDERALIST NO. 51, at 323 (James Madison) (Jacob E. Cooke ed., 1961). On the other hand, the term "department" is typically viewed as associated with departments within the executive. See Lawrence Lessig \& Cass R. Sunstein, The President and the Administration, 94 COLUM. L. REv. 1 passim (1994) (explaining the origins of administrative departments). The Constitution itself uses such terminology. See U.S. CONST. art. II, § 2, cl. 2 (providing that the power of appointment of inferior officers may be made by "the Heads of Departments"). Because of my emphasis on constituency, I have chosen the nomenclature that leaves the term "branch" available to distinguish the Senate and the House from the entire Congress.

26. See Redish \& Cisar, supra note 17, at 455 ("The key point, however, is that no matter how the terms are ultimately defined, the exercise of each branch's power is to be limited to the functions definitionally brought within those concepts."). 
reside in the executive department, judicial powers in the judiciary, and legislative powers in the Congress, we will be safe. The formalists' liberal antagonists, the so-called functionalists, seem at times to accept this underlying notion of functional separation, urging only that the descriptions be broadened or that the overlap not be "too great." ${ }^{27}$ Although borrowing the vocabulary of realism ${ }^{28}$ and choosing to embrace a balance of power, ${ }^{29}$ many functionalist approaches, like formal ones, retain explicit attachment to the concept of function. For example, when the Supreme Court uses a functionalist approach, it asks whether the challenged practice undermines an existing departmental function, an inquiry that frequently leads the Court to ask what function the challenged practice performs. ${ }^{30}$

Much of the commentary on the separation of powers makes similar assumptions. Legal scholars who believe that we should aspire to a more rigid set of departmental boundaries, ${ }^{31}$ as well as those who would loosen them, ${ }^{32}$ begin with function. ${ }^{33}$ So, too, do those who be-

27. For a succinct and careful description of formalism and functionalism, see Kathleen M. Sullivan, Comment, Dueling Sovereignties: U.S. Term Limits, Inc. v. Thornton, 109 HARV. L. REV. 78, 92-95 (1995). On the relationship between formalism and functionalism, see Brown, supra note 24, at 1530 (arguing that the debate surrounding both models "hangs in midair, moored to no grander objective"); Strauss, supra note 24, at 488-94 (rejecting formalism in favor of functionalism for the administrative levels of government); Mark Tushnet, The Sentencing Commission and Constitutional Theory: Bowls and Plateaus in Separation of Powers Theory, 66 S. CAL. L. REV. 581, 596 (1992) (arguing that formal and functional approaches "converge").

28. See Tushnet, supra note 27, at 603 ("Functionalism is appealing ... because it resonates with a hard-nosed realism ...."). Functional argument has a long and venerable history in realist thought. See generally Felix S. Cohen, The Problems of a Functional Jurisprudence, 1 MoD. L. REV. 5 passim (1937) (surveying the role of functionalism in legal science as a means of addressing previously ignored legal questions).

29. See Martin S. Flaherty, The Most Dangerous Branch, 105 YALE L.J. 1725, 1732 (1996) (emphasizing balance-of-power analysis as the hallmark of the functional approach).

30. See, e.g., Morrison v. Olson, 487 U.S. 654, 685 (1988) (inquiring whether a "good faith" removal provision "impermissibly" interfered with the executive function). It also requires a comparison of the "function" of the challenged practice with the "function" of a department. See Nixon v. Administrator of Gen. Servs., 433 U.S. 425, 443 (1977) ("[I]in determining whether the Act disrupts the proper balance between the coordinate branches, the proper inquiry focuses on the extent to which it prevents the Executive Branch from accomplishing its constitutionally assigned functions.").

31. See, e.g., Steven G. Calabresi \& Kevin H. Rhodes, The Structural Constitution: Unitary Executive, Plural Judiciary, 105 HARV. L. REV. 1153, 1159 (1992) (arguing that the Vesting Clauses of Articles II and III strongly support a unitary executive theory); Carter, supra note 23, at 138-39 (criticizing the independent counsel ("IC") statute as an illegitimate breach of the separation of powers doctrine); Redish \& Cisar, supra note 17, at 455 ("[T]he exercise of each branch's power is to be limited to the functions definitionally brought within those concepts.").

32. See, e.g., Elliott, supra note 22, at 509 ("[L]iteralism is stifling separation of powers jurisprudence ...."); Paul Gewirtz, Realism in Separation of Powers Thinking, 30 WM. \& MARY 
lieve that separation of powers disputes are nonjusticiable or incoherent. ${ }^{34}$ Unfortunately, almost everyone ends with function, too; for it is also widely believed that the Constitution itself defies the dream of functional separation $^{35}$ and that the Supreme Court has demonstrated its inability to delineate clear functional lines. ${ }^{36}$

\section{A. A Vertical Challenge}

If the only problem were one of fuzzy boundaries or uncertain norms, there might be no reason to reconsider old assumptions about the separation of powers. But recent events have suggested that there is a wide gap between what is perceived as a serious shift in power and the law of separate constitutional powers. Many believe that the Supreme Court failed to appreciate the dangers of the independent counsel ("IC") law or the implications of judicial supervision of a sitting President. Although this may make the task salient, I confess at the start that the source of my concern does not lie in current events

L. REV. 343, 343 (1989) ("[R]igid categories of branch power simplistically disregard the real complexities of government structure as we know it ....").

33. Indeed, even those who begin with history begin with function. See GERHARD CASPER, SEPARATING POWER 1 (1997) ("The separation of governmental powers along functional lines has been a core concept of American constitutionalism ever since the Revolution."); Flaherty, supra note 29, at 1730-31 (emphasizing the importance of a historical understanding that assumes the validity of the functional ideal). But see Christine A. Desan, The Constitutional Commitment to Legislative Adjudication in the Early American Tradition, 111 HARV. L. REV. 1381, 1385 (1998) (questioning the projection of modern concepts of judicial function onto early American practice)

34. See, e.g., Jesse H. Choper, Judicial Review And the National Political PROCESS 263 (1980) (arguing that separation of powers controversies between the Congress and the President are nonjusticiable political questions); Tushnet, supra note 27, at 584-85 (arguing that the traditional ways in which scholars and courts look at separation of powers tend to converge).

35. For example, the Constitution does not grant to the President powers that are solely executive in nature. See, e.g., U.S. CONST. art. I, § 7, cl. 2 (granting the President power to return, and thus to reject, the policy pronouncements of Congress and placing this power within Article I, not Article II). Similarly, the Congress is not granted powers that are exclusively legislative in nature. See, e.g., id. art. I, $\S 3$, cl. 6 (granting the Senate the power to try impeachments); id. art. II, $\S 2$, cl. 2 (granting the Senate the power to consent to executive appointments).

36. Justice Stevens has openly acknowledged that "governmental power cannot always be readily characterized with only one of ... three labels." Bowsher v. Synar, 478 U.S. 714, 749 (1986) (Stevens, J., concurring in the judgment); see also id. at 750 (noting that "[t]he powers delegated to the Comptroller General by $\S 251$ of the Act ... have a ... chameleon-like quality"); id. at 751 ("Under the District Court's analysis, and the analysis adopted by the majority today, it would therefore appear that the function at issue is 'executive' if performed by the Comptroller General but 'legislative' if performed by the Congress."). 
but in my reading of history and my understanding of political power. I believe that it is fairly easy to see that the Framers had a far more sophisticated and realistic sense of the dangers of shifting political power than most lawyers have today. Although recent events may jar those with conventional ideas to reconsider their position, we might have known this all along.

The resistance lies, I believe, in the seeming incontestability of a very basic concept - that the object of a law of separate powers is to torture the departments into legal descriptions of what is legislative, executive, and judicial. I think that this descriptive project has failed, and obviously so; it is an open secret that the departments all perform the functions of other departments, yet the Court, scholars, and students continue to talk as if they could make the descriptions work. My own belief is that the Constitution constitutes the departments as much as it describes them, creates political relationships as much as it confines them. ${ }^{37}$ The key to maintaining a healthy separation of powers as a particular form of republican government is attention not only to the descriptive but also to the constitutive aspects of political power. Willard Hurst said it long ago: law is not only a tool of control, but also a means of releasing energy. ${ }^{38}$ Our Constitution is a means of both limiting and creating political power. Any complete understanding of shifting power must grapple with the political incentives that constitutive power creates.

The premise of the vertical approach is simple: if, as the constitutional text makes quite clear, the departments are created by various political relationships-by voting, by representation, by appointment - then we must pay attention to those relationships in considering shifts in power. In one sense, this is obvious: shifting the war power to the Supreme Court shifts political relationships as well as tasks; it significantly weakens the people's power to decide whether to go to war. This reflects an equally obvious but broader principle that changing the nature of the constituencies that control government can change the form of that government. Put decisionmaking power in the hands of the few, and you lurch toward aristocracy; put it in the hands of the many, and you invite the mob; take away the

37. This is not a new insight. See Charles L. Black, Jr., Structure AND RELATIONSHIP IN CONSTITUTIONAL LAW (1969).

38. See HURST, supra note 12, at 7 (arguing that the proper understanding of 19th-century law was not "the jealous limitation of the power of the state, but the release of individual creative energy"). 
representative relationship altogether, and you risk anarchy or autocracy. The vertical approach asks whether and how the shifting of tasks among government players affects "who" will decide, where the "who" appears as the constituencies creating the departments, and where the risks are not descriptive impurities, but structural incentives likely to change political relationships between the governed and their governors.

Verticality seeks to identify constitutional harm in something more than the transcendental-more than "too much" power, "balance" disrupted, or "functions mixed." The vertical approach posits that the constitutional danger in shifting functions lies in popular silences and amplifications, in empowering some constituencies at the expense of others. Under this view, the problem with sending the war decision to the Court is not the bad descriptive fit between war and judicial function but the silencing of national and local constituencies on such an important issue-that the Court will go to war without the people. As the Founders might have said, the fear is that, if we give the war power to the Court, we will have traded the people's decision for one by an elite, that we will have exchanged democracy for aristocracy.

Rather than looking for a description to impose from the "topdown," the vertical approach considers power from the "bottomup"- as a function of the people who grant it to the governmentand thus is an explicitly populist approach. It takes seriously, as a matter of constitutional law and theory, what Hannah Arendt made clear so long ago-that "when we say of somebody that he is "in power' we actually refer to his being empowered by a certain number of people to act in their name. ${ }^{, 39}$ With this shift from the categorical to the relational idea of political power, ${ }^{40}$ the question is not what power has changed hands, where the power belongs, or whether the power shifted is too much, but who will wield that authority and what comparative risks that shift in decisionmaker entails for constitutional relationships between the people and their government.

The vertical approach, then, locates constitutional risk, quite literally, in constituent harm-in the relationship between changing constituencies and forms of government. The Framers knew that a republic depends for its form upon the ways in which it "mixes" coun-

39. ARENDT, supra note 10 , at 44.

40. See infra Part IV (discussing this as a shift from a lawyerly ideal of power as command to a constitutional ideal of power as constitutive). 
tervailing forms of representation. ${ }^{41}$ Indeed, the unique genius of the constitutional plan was its ability to mediate self-interest through three forms of popular sovereignty, government by three differently aggregated constituencies: the states, the localities, and the nation. ${ }^{42}$ It is in changing the relative strength of these political relationships that we shift power in the sense of changing the form of our government. It is this that the law of the separation of powers should illuminate.

\section{B. A Hypothetical Constitution}

Let us engage in an intellectual experiment. To test the power of the conventional functional approach, let us imagine a different constitution. In what follows, I will use that hypothetical constitution to show how the functional understanding of political power cannot describe what we know to be major changes in constitutional structure. I will also use it to show that shifts in power can often be better understood as shifts in political relationship and incentive-that what we mean when we say that power has changed hands is that the decisionmaker has changed.

Our hypothetical constitution resembles our own in all apparently significant ways. There are three major institutions: the judiciary, the executive, and the legislature. Each institution is described in precisely the same constitutional terms. The Vesting Clauses are identical $^{43}$ and the departments' enumerated powers ${ }^{44}$ are largely the

41. For a discussion of mixed government and its influence on the founding and in The Federalist Papers, see Nourse, supra note 10, at $455 \&$ nn.34, 482.

42. See id. at 500-01. By suggesting that local constituencies had a role in the original constitutional plan, I do not mean to imply that district elections are constitutionally compelled by Article I. Although the Constitution itself is not particularly clear on this question and electoral practice has varied over time, see infra note 50, supporters of the Constitution, including Madison, appeared to assume that federal representatives would be elected by districts and that this was essential to ensure equality of representation. See THE FEDERALIST No. 57, at 389 (James Madison) (Jacob E. Cooke ed., 1961) ("Some of [Pennsylvania's] counties which elect her State representatives, are almost as large as her districts will be by which her [Federal] Representatives will be elected. The city of Philadelphia ... will therefore form nearly two districts for the choice of [Federal] Representatives."); ANDREw HACKER, CONGRESSIONAL DisTRICTING 8-14 (1963) (arguing that Madison's attachment to districting was animated by a concern that "the people" be represented in the House rather than a "selective group defined by property and family connections" and that "the concern of Madison, King, and Pinckney that districts be equal in size was an institutional step in the direction of securing this democratic principle"). For most purposes, House members will be relatively more locally tied than the President or the Supreme Court, however they are elected.

43. See supra note 1 .

44. By "enumerated powers," I mean powers the Constitution specifically describes as 
same. There are, however, three differences between this hypothetical constitution and the real one. First, our imaginary constitution provides that the House of Representatives shall elect the members of the Senate; second, it decrees that the Congress's say is final on all legislation, omitting any approval or disapproval by the President; and third, it states that the Congress is permitted to appoint important members of the executive branch. Lest this seem, at the outset, like a farfetched academic enterprise, one has only to refer to the debates of the Constitutional Convention to see that this might very well have been our Constitution. Similar proposals were considered but rejected in $1787 .^{45}$

\section{Political Relationships}

The first difference in my hypothetical constitution is explicitly one of constituency: the House is to elect the Senate. Would that change our constitutional arrangement of powers? In one sense, the answer seems obviously yes. And, yet, we cannot know this from a claim that there is a change in function. Under my hypothetical constitution, the House and Senate retain the same function-they still legislate. And, yet, it is fairly easy to see that this proposal would effect dramatic changes in our government. To be blunt, we would have one, not two, houses of Congress. Beholden to the House for their

powers. See U.S. CONST. art. I, § 8, cls. 1-18 (beginning with "[t] $]$ he Congress shall have Power To...." and listing the specific powers of Congress); $i d$. art. II, $\S 2$, cls. 1-3 (stating that "[t]he President shall be Commander in Chief of the Army and Navy .... He shall have Power, by and with the Advice and Consent...." and listing other specific powers of the President); id. art. III, § 2, cl. 1 (declaring that "[t]he judicial Power shall extend to all Cases, in Law and Equity, arising under this Constitution...." and listing other specific powers of the judiciary). This leaves out items typically associated with some departments. For example, the Bicameralism and Presentment Clause, which gives the President the "power" to veto, is not included in Article II's list of presidential powers but appears instead as a limitation on the Congress. See id. art. I, § 7, cl. 2 ("Every Bill . . . shall, before it becomes a Law, be presented to the President of the United States; If he approve he shall sign it, but if not he shall return it, with his Objections ....").

45. The Virginia plan, which in amended form became our Constitution, originally provided that "members of the second branch of the National Legislature ought to be elected by those of the first...." 1 THE RECORDS OF THE FEDERAL CONVENTION OF 1787, at 20 (Max Farrand ed., rev. ed. 1966) [hereinafter FARRAND's RECORDS] (recording the May 29, 1787, resolutions proposed by Edmund Randolph of Virginia). The New Jersey Plan, a competing proposal supported by a minority of States, provided the President with no veto power. See id. at 242-45. The Virginia Plan proposed that the executive (which was thought by many to be made up of multiple persons) be appointed by the Congress. See id. at 20 ("Resd. that a National Executive be instituted; to be chosen by the National Legislature for the term of years ...."). 
election, Senators would have little incentive to depart from the interests of House members. Their constituents, in effect, become those of House members. As George Mason put it at the Constitutional Convention when arguing against just such a proposal: it "would be highly improper to draw the Senate out of the first branch ... [because] it would make the Members too dependent on the first branch. ${ }^{, 46}$

If we know that this proposal would effect major changes in the relationship between the House and Senate, we do not know it because of text or even because of function. The text has not changed: the Vesting and Bicameralism Clauses remain the same. ${ }^{47}$ Nor has function changed: the Senate has not aggrandized itself by seeking executive or judicial functions. What has changed, however, are the political relationships that govern the Senate's incentives to act. The Constitution assumes that elected officials will speak, however imperfectly, to those who elect them. Under our hypothetical constitution, however, Senators will no longer address their speeches to the people of their state as they do today, or even to their state legislatures as they once did, but instead will speak to the members of the House of Representatives.

With that change in constituency, we can predict a change in incentive, and from there a change in the relationship between the House and the Senate. Since Senators are beholden to House members under our hypothetical constitution, Senators will tend to act as House members wish them to act. ${ }^{48}$ Put another way, we can see that this hypothetical constitution would push us toward a Congress that would look far more like a unicameral legislature. The important

46. Id. at 59; see also id. at 52 (statement of James Wilson) (urging the Convention to reject of a proposal to have the House members elect Senators, as this would make the Senate too dependent on the House).

47. By "text", here I mean the text conventionally associated with the powers of Congress and the relationship of its branches. Under my hypothetical constitution, as under our own, Article I would still vest legislative powers in the Congress. See U.S. ConST. art. I, § 1 ("All legislative Powers herein granted shall be vested in a Congress of the United States, which shall consist of a Senate and House of Representatives."); id. art. I, $\S 8$ (enumerating legislative powers). Moreover, the Bicameralism Clause, requiring that a bill be passed by both houses before becoming law would also be identical. See id. art. I, § 7, cl. 2.

48. That we might wish "independence" upon these Senators does not mean that the structure in which they find themselves is conducive to that independence. In this sense, my hypothetical is a kind of worst-case scenario; I assume, as did the Framers, that in designing structure, it is wise to assume that governmental players will act as structural incentives suggest, even if we hope that they also act as conscience demands. See THE FEDERALIST No. 51, supra note 25 , at 349 . 
point to see here is that, by changing the Senate's constituency, we may change no function, but we may risk significant change to our form of government. We change the relation not only of the House to the Senate but also of the Congress as a whole to the other departments. For few would doubt, and the Framers certainly understood, that a unicameral legislature poses a far more powerful challenge to the judiciary and the executive than does a bicameral one. Indeed, in Madison's view, a bicameral legislature was essential to maintaining the separation of powers for precisely these reasons. ${ }^{49}$

What started out, then, as a change in vertical structure-shifting the political relationships providing for the election of Senatorsturns out to affect horizontal structure-the distribution of power among the three departments. The idea that vertical political relationships may affect the separation of powers is hardly without precedent, but, in a sense, it is so obvious as to be invisible. We know that the Constitution not only describes power in functional terms but also creates democratic constituencies and other political relationships of appointment and removal. Lawyers learned in their tenth-grade civics class that the states elect Senators, local districts elect members of the House of Representatives, ${ }^{50}$ and the nation as a whole elects the President. ${ }^{51}$ Of course, there are many complications to this picture, ${ }^{52}$ but the basic premise should suggest, at least, that

49. Because Madison feared an all-powerful legislature, he thought it necessary to break the legislative power in two in order to match more equally the less-powerful executive and the courts. See id. at 350.

50. In fact, the practice for electing House members has varied over time. Until the 17th Amendment was ratified in 1913, Senators were elected by state legislatures. During most of this period, the House was elected primarily through districts, with the exception that, before 1842 , as many as nine small states chose to hold at-large elections. See SAMUEL IsSACHAROFF ET AL., THE LAW OF DEMOCRACY 771 (1998) (discussing the Reapportionment Act of 1842). By 1842 , Congress had required that all states vote by district for House seats. This statutory restriction lapsed from 1929 to 1967, and yielded occasional state departures from strict district voting, but the districting requirement was reinstated in 1967. See id. at 772 . Today, the only exceptions to this are the inevitable ones that arise in the few states that have a single congressional representative. See id. Although this history is complex and intriguing, it does not change the risks of a scheme in which House members elect all Senators (risks well known to the Framers) or the risks of a scheme in which all House members have statewide constituencies-a practice never followed under our Constitution.

51. See, e.g., U.S. CONST. art. I, $\S 2$ (providing for the election of members of the House of Representatives); id. art. I, $\S 3$, cl. 1 (providing for the election of members of the Senate); id. art. II, $\S 1$, cls. 2-3 \& amend. XII (providing for the election of the President). The original electoral Constitution has been amended in several ways, most notably, to change the ways in which Senators are elected. See id. amend. XVII (providing for the direct election of Senators).

52. The electoral college complicates matters for the President, for example, and indeed there may be scenarios, such as the one-congressional-district state, in which a small number of Senators and Representatives are representing the same constituencies. See supra note 50 (dis- 
but the basic premise should suggest, at least, that significant acrossthe-board changes in these fundamental electoral relationships could change political incentives and thus structure. Indeed, a focus on participation and incentive is the basic core of the approach taken by many economists and political scientists toward political power. ${ }^{53}$ To lawyers, however, this may come as something of a shock, for it invites them to question whether their way of understanding powerpower as function or Vesting Clause description-may fail to predict important shifts in governmental structure. Certainly, a theory that failed to warn of significant dangers to bicameralism is not one that would have been acceptable to those who relied upon it to help secure the separation of powers. ${ }^{54}$

Now, consider the second provision of my hypothetical constitution: the proposal to eliminate the President's veto. ${ }^{55}$ Of course, few would embrace the constitutionality of a move to eliminate the veto.

cussing the districting question). Nor may it have been the founding vision. See ACKERMAN, supra note 11, at 69. As Ackerman notes, however, the original vision has changed: "We expect Senators to take a broader, more nationalistic, perspective than the typical Representativealthough each Senator's partiality to his own state still makes him seem relatively provincial compared to the plebiscitarian President who constantly explains that he is the only official elected by all Americans...." Id. For my purposes, these complications are largely without significance. Relatively, the constituencies of the three departments as a whole remain geographically and otherwise distinguishable.

53. See, e.g., JON ELSTER, POLITICAL PSYCHOLOGY 29 (1993) (equating arguments on the "incentive effects" of the constitutional scheme with public choice theory and the political theory of the Framers); Positive THEORIES OF CONGRESSIONAL InSTITUTIONS 8, 15 (Kenneth A. Shepsle \& Barry R. Weingast eds., 1995) (describing how a second generation of positive political theorists have "suggested ways in which institutional structure channel[s] expressions of legislative self-interest" and how various kinds of organizational choice establish "institutional incentives" to avoid problems such as lack of information); Neil K. Komesar, Job for Judges: The Judiciary and the Constitution in a Massive and Complex Society, 86 MiCH. L. REV. 657, 672-74 (1988) [hereinafter Komesar, Job for Judges] (relying upon the incentives of members of majorities or minorities to evaluate likely outcomes and appropriate institutional choices); see also Christine Jolls et al., A Behavioral Approach to Law \& Economics, 50 STAN. L. REV. 1471, 1487 (1998) (equating a focus on "incentive effects" with traditional law and economics scholarship).

54. See THE FEDERALIST No. 51, supra note 25, at 350 (arguing that bicameralism is essential to maintaining the independence of the departments).

55. See U.S. CONST. art. I, § 7, cl. 2 ("Every Bill ... shall, before it become a Law, be presented to the President of the United States; If he approve he shall sign it, but if not he shall return it, with his Objections ...."). As noted supra note 44, the so-called veto power is not an enumerated power of the President under Article II, but instead it appears under Article I, which governs the passage of legislation. Otherwise, all enumerated powers of the presidency in Article II remain the same in my hypothetical constitution, with the exception of the Appointment Clause powers. See, e.g., U.S. CONST. art. II, §§ 2-3 ("The President shall be Commander in Chief of the Army and Navy .... He shall have Power, by and with the Advice and Consent .... [H]e shall take Care that the Laws be faithfully executed ...."). 
But note that there is nothing in current functional approaches that would necessarily bar this proposal. Eliminating the veto does not force Congress to adjudicate or the President to legislate; both before and after the proposal, the President is still executing, ${ }^{56}$ the Congress legislating, and the courts adjudicating.

If function cannot give us a satisfactory reason why the veto is not mere surplusage, it is unlikely to give us a satisfactory reason in more difficult cases. The important point to see here is that if function does not warn us of a major shift in power, the vertical approach may. Without the veto, not only is the Congress more powerful, but its constituencies (local and state) become more powerful relative to the President's national constituency. Once we consider these vertical effects, we come to see quite easily what the Framers did: that a constitution without a presidential veto is a constitution in which far more power is granted to the states and localities. After all, the Antifederalists opposed the veto power because they wanted to protect the power of state and local constituencies, ${ }^{57}$ not because the veto failed to fit the proper description of an "executive" function.

When our Constitution provides that the President may veto the acts of the Congress, it permits the political departments to discipline each other in a particular order. The veto is not only a check by one department of government against another but also one of the important ways in which the Constitution gives primacy to national con-

56. Lest one think it impossible to have a President without a veto, it is worth noting that a number of state constitutions, drafted prior to the Constitutional Convention, included no veto for the chief executive, see Flaherty, supra note 29, at $1761 \&$ n.181, and that the New Jersey plan, offered at the Constitutional Convention, included provisions for an executive with no veto power, see 1 FARRAND's RECORDS, supra note 45, at 244.

57. One of the Antifederalists' principal objections to the Constitution was that it would "destroy the states and produce a consolidation." GORDON S. WOOD, THE CREATION OF THE AMERICAN REPUBLIC 1776-1787, at 529 (1969); see also FEDERALISTS AND ANTIFEDERALISTS 1 (John P. Kaminski \& Richard Leffles eds., 1988) ("Antifederalists argued that the Constitution would destroy the states and create one large, consolidated republic that would deteriorate into monarchy or despotism."). This reflected the Antifederalists' fundamental fear that the "very structure" of the "new national government" and its "detachment from the people would work to exclude any kind of actual and local interest representation ...." WoOD, supra, at 516. Antifederalists opposed the President's veto power, see JACKSON TURNER MAIN, THE ANTIFEDERALISTS 141 (1961) (noting the Antifederalists' opposition to the President's veto), as they did many other features of the Constitution, on the grounds that it would increase the possibility of consolidation and monarchy and thus decrease the power of direct representation. See, e.g., The Address and Reasons of Dissent of the Minority of the Convention of Pennsylvania to Their Constituents (Dec. 18, 1787), reprinted in THE ANTI-FedERALIST PAPERS AND THE Constitutional Convention Debates 247-48 (Ralph Ketcham ed., 1986) (explaining how the veto increased the likelihood of "unadequate [sic] and unsafe" representation). 
stituencies relative to those of states and localities (unless those localities muster significant evidence of national sentiment, a supermajority). ${ }^{58} \mathrm{We}$ are all familiar with the concept of checks. What may not be so obvious, however, is that these "disciplining relationships" can be conceived less as tools for departments to compete with each other than as ways in which the Constitution regulates political relationships: if the Congress were to have power to veto the President, we would not only shift power in a raw, undefined sense, but, more specifically, we would give real primacy to those whom Congress represents. ${ }^{59}$ And this occurs without regard to functional labels: whether we call the President's veto an exercise in legislative or executive power, its real effect is to permit the President's constituency (the nation) to veto the wishes of a majority of the states and localities, thus implementing and reinforcing the Supremacy Clause..$^{60}$

The vertical approach not only highlights the role of changing political relationships and their effect on the form of government, it can also help us to see connections between the separation of powers and issues that have appeared somewhat "technical" and removal powers. Consider our third hypothetical provision in which the House and Senate would choose officers to sit in the executive department. From a functional perspective, there may seem little harm from this arrangement. The appointment process does not noticeably interfere with passing legislation, executing laws, or deciding cases; both before and after the proposal, the Congress continues to legislate, the President to execute, and the courts to adjudicate. (Indeed, since the Senate confirms appointees, ${ }^{62}$ one might even argue that the appointment "function" is not foreign to the Congress.)

58. Article I makes clear that the President may work his will on legislation unless the Congress can muster a supermajority. See U.S. CONST. art. I, § 7, cl. 2.

59. To fend off the student of federalism at the start, my claim is not that the national legislature protects the states, as is argued in Herbert Wechsler, The Political Safeguards of Federalism: The Role of the States in the Composition and Selection of the National Government, 54 Colum. L. REV. 543 (1954), only that the legislature's political constituencies create greater incentives to cater to local interests than does the President's national constituency. That would be true whether or not the legislature routinely betrayed the states as governmental entities.

60. U.S. CONST. art. VI, cl. 2 ("This Constitution, and the Laws of the United States which shall be made in Pursuance thereof ... shall be the supreme Law of the Land; and the Judges in every State shall be bound thereby, any Thing in the Constitution or Laws of any State to the Contrary notwithstanding.").

61. Morrison v. Olson, 487 U.S. 654, 703 (1988) (Scalia, J., dissenting).

62. See U.S. CONST. art. II, $\S 2$, cl. 2 (granting the Senate confirmation power over the President's nominations). 
If we know that this "appointment" proposal would change constitutional structure, it is not because we have consulted the definition of legislative, executive, or judicial power or even the Appointments Clause. ${ }^{63}$ We know that power has shifted because political relationships have changed. Simply imagine the Congress exercising power over the salary or the tenure of judges and one can see that questions of "personnel" are no trivial matters-they may determine the relative independence of an entire department. ${ }^{64}$ Similarly, it should be fairly easy to see that, should Congress gain control over individual executive department employees, Congress's power would increase relative to the President. What may be harder and yet more important to see is why this is-even if there is no impairment of function.

Again, the vertical approach is helpful. If the President's men turn out, in fact, to be Congress's men, then there is a risk, quite literally, that the President's incentives and constituency have changed. Consider, for example, a Clinton administration staffed by friends of Trent Lott or Bob Dole or Newt Gingrich, the President's political opponents. The President as agent of a national constituency might now worry that his administration reflects less the hopes and fears of the nation than of Kansas, Georgia, and Mississippi. ${ }^{65}$ What is at stake in matters of appointment or removal is not simply a technical question or even a question about the relationship of Congress and President but the relationship between state and federal constituencies. Again, this was not lost on the Framers, ${ }^{66}$ many of whom recognized

63. See Buckley v. Valeo, 424 U.S. 1, 140 (1976) (construing the Appointments Clause to bar certain congressional involvement in appointments of those performing administrative functions that could only be exercised by "Officers of the United States" (quoting U.S. CONST. art. II, § 2, cl. 2)).

64. See Nourse, supra note 10 , at 471-77.

65. I do not mean to suggest that the President does not have an incentive or interest in pleasing the states; the electoral college provisions do create such incentives. The question is whether this proposal (which inserts into the executive department those with an incentive to please congressional representatives) would, as a relative matter, increase the executive's incentives to cater to state interests at the expense of the national interest.

66. By 1787, it was well known that the Congress and the President could not remain separate institutions if the Congress had control over members of the executive department. See, e.g., Statement of James Wilson Before the Pennsylvania Convention (Dec. 11, 1787), in 2 THE DOCUMENTARY HISTORY OF THE RATIFICATION OF THE CONSTITUTION 550, 567 (Merrill Jensen ed., 1976) ("To have the executive officers dependent upon the legislative would certainly be a violation of that principle so necessary to preserve the freedom of republics, that the legislative and executive powers should be separate and independent.”). 
that if Congress had complete control over members of the executive branch, the presidency would "slide into ... the Legislature."

\section{BRIDGING THE REALISM GAP}

If the vertical approach helps to give us a new perspective on separation of powers controversies, it must help in a real constitution, not simply a hypothetical one. Recent events have suggested that there is a broad gap between the nation's political life and the Supreme Court's analysis of the risks of structural change. In this part, I explain why I believe that the vertical approach may help us ask questions that bridge that "realism" gap in the separation of powers. To flesh out an alternative vertical approach, I consider what it might have told us about the Supreme Court's decisions in Clinton v. Jones ${ }^{68}$ and Morrison v. Olson, ${ }^{69}$ as well as in the Court's recent federalism cases. I leave to Part III full explication of the approach in theory.

\section{A. Can a Man "Happen" to Be President?}

Clinton $v$. Jones is known as a case about executive function and presidential immunity. ${ }^{70}$ Faced with the question whether the President could be sued by a private party, Paula Jones, the Supreme Court rejected the President's arguments that the judicial consideration of this suit would violate the separation of powers, concluding that the suit would in no way impair executive or judicial "functions." entirely to the unofficial conduct of the individual who happens to be the President poses no perceptible risk of misallocation of either judicial power or executive power.",72

67. As Madison warned Edmund Randolph in a private letter during the removal debate of 1789 , if the Senate were to be given control over members of the executive department, "the Ex[ecutive] power would slide into one branch of the Legislature." Letter from James Madison to Edmund Randolph (June 17, 1789), in 12 THE PAPERS OF JAMES MADISON 229, 230 (Charles F. Hobson \& Robert A. Rutland eds., 1979). For a far more extended argument about the importance of appointment and removal to maintaining constitutional structure, see Nourse, supra note 10 , at $456-61,469,514-19$.

68. 520 U.S. 681 (1997).

69. 487 U.S. 654 (1988).

70. See, e.g., Neal Kumar Katyal, Judges as Advicegivers, 50 STAN. L. REV. 1709, 1754-55 (1998) (criticizing the Court's opinion for its focus on the immunity issue to the exclusion of structural considerations).

71. See Jones, 520 U.S. at 702-06.

72. Id. at 701 . 
Read today, with the knowledge that the Jones suit led to the impeachment of a sitting President, it seems difficult to understand the Supreme Court's confidence that "there is no possibility that [its] decision will" have a significant effect upon the presidency. ${ }^{73}$ And, yet, from a functional perspective, the Court's analysis seems perfectly plausible. This proposal, like the ones in our hypothetical constitution, does not require that the President perform any new or incompatible function; nor does it seem to require the courts to take on executive responsibilities. Indeed, the Supreme Court seems quite right to conclude that the President's inconvenience was insufficient to overcome the plaintiff's right to be heard. Balancing the "inconvenience" of a private suit against the "rule of law," the Court not surprisingly decided that the suit should go forward. ${ }^{74}$

The issue remains whether the functional inquiry identifies all the constitutional risks at stake. No one was really claiming in Clinton $v$. Jones that the President could not be sued, only that he could not be sued while in office. ${ }^{75}$ That should have raised, for the Court, the question of constituency and political relationship. For what is the difference between a President after his term and a President during his term but the interests of those who empower him? In a republic, a President does not "happen[]" (as the Court put it); he is elected, and, as an elected official, he exercises the political authority granted him by a national constituency. From the vertical perspective, then, the question in Clinton is not simply about inconvenience or even the rule of law, but the risks to the people the President represents. Put more colloquially, a civil lawsuit against a sitting President may be problematic not because the President is in any sense above the law (he is not), but because the courts, which are political outsiders in our system, ${ }^{77}$ are not above the people. ${ }^{78}$

73. Id. (emphasis added).

74. See id. at 706-08.

75. Indeed, the Supreme Court seemed to concede this at one point. See id. at 697 (noting that the President did not argue that he was completely immune from judicial scrutiny but rather that he was permitted a postponement of any such proceedings).

76. Id. at 701 .

77. By branding courts as relative outsiders to the political process, I do not mean to suggest that courts are completely unrepresentative institutions. On the representative elements of courts, see Christopher J. Peters, Adjudication as Representation, 97 Colum. L. Rev. 312 (1997). As a relative matter, however, it seems uncontroversial to conclude that courts do not speak directly to a particular geographic constituency, as does Congress or the President. I emphasize here and elsewhere that this analysis focuses on relative shifts in power, not absolute ones. See infra Part III. 
To see the risks, it is important to remember that a President sued is a President who may lose a suit and that a President who may lose a suit is a President who will do political battle over that loss. No matter how trivial or private the suit may seem-from a bad debt to a slip-and-fall-if the President is adjudged to be negligent or to defalcate, his loss will not simply be the loss of a private citizen but the loss of a President, a player in that institutional competition we know as the separation of powers. It is not too difficult to predict how a presidential loss in a suit about drunk driving or bad debts might create an incentive for the President's political opponents to step up their attacks or even lead to impeachment. ${ }^{79}$ What may be more difficult to see is how a judicial ruling changes the President's fate in that political battle. It is the judicial proceeding that transforms public denials into claims of perjury, that transforms a private matter of a debt or a slip-and-fall into a violation of the "rule of law." With or without a judicial ruling, the facts that led to the Jones suit might well have been the subject of an impeachment proceeding. With a court ruling, however, the case for impeachment changes: whether the court says it is avoiding politics or not, its decision puts the judicial imprimatur, institutional legitimacy, even the rule of law, on one side of the political debate. And, with this, the court risks acquiring power to determine (even if in small part) the political fate of the nation and its President. $^{80}$

Traditionally, the separation of powers issue in Jones is seen as one of executive power, but, if this is right, the question turns out to be less about the executive than about the judiciary. Indeed, it is a question less about the relation of the President to the courts than that of the Congress to the courts. The separation of powers risk is that the court is (inadvertently, perhaps, or even against its wishes) acquiring a political role in "checking" the President, a role typically left to Congress. As a general rule, our constitutional system leaves it to the politically responsive branches to do battle by means of over-

78. This is not to say, however, that we do not value or prize courts' countermajoritarian pedigree to the extent that it serves to restrict majorities' tendency to tread upon the rights of minorities. It is to say, however, that countermajoritarianism also poses risks, risks that should be assessed openly rather than simply denied.

79. Although no one will actually believe this, early drafts of this argument were written before the recent presidential impeachment. Ten years in Washington taught me something about political incentives.

80. Even if the risk of this might not be great in some instances, the cost may be very high to the Court in the long run, particularly where the issue really is whether to postpone the suit rather than to dismiss it. 
sight and impeachment. Shifting even a small part of that power to the courts, relative political outsiders, and away from Congress and its direct constituency relations ${ }^{81}$ should represent a serious separation of powers question. Why? Because it risks shifting a matter of great public import to those least responsive to the people.

There are, of course, important countervailing interests at stake in the Jones case-the interests of the plaintiff and private litigants generally. Indeed, it is these interests that make many appeal reflexively to notions of the "rule of law" and "individual rights." The vertical approach suggests, however, that this kind of move may be a bit too easy; indeed, that these very concerns might be more likely to be satisfied by postponing, rather than proceeding with, the lawsuit. As we will see in some detail later, ${ }^{82}$ shifts in constituency typically do not simply lead to one kind of risk. Shifts from a more to a less politically tied body tend to increase minoritarian risk-the risk that a minority may silence a majority; at the same time, shifts from a less to a more politically tied body tend to increase majoritarian risk-that a majority will silence a minority or individual. Jones raises not only the question whether the Court's ruling will place the unelected in charge of the nation's political life (minoritarian risk) but also whether it will subject individual litigants to the vagaries of the nation's political life (majoritarian risk). Put another way, if one is really concerned about Paula Jones's fate, one must worry that, if the suit is to proceed while the President is still in office, politics might inevitably affect the judgment in her case. There is always the risk that any judge empowered to rule against the nation's leading political figure will be influenced by majoritarian politics in making her ruling, ${ }^{83}$ whether it is in

81. One might argue that Jones shifts the power to check the President from the Congress to individual litigants. As in the case of shifting such power to an elite court, this kind of shift also poses a minoritarian risk-that the litigants, like Paula Jones, will not really represent the nation's collective interest any more than courts are capable of doing. Indeed, this is precisely the danger of having "impeachment-by-litigation," rather than by Senate trial or new electionthe risk is that a single citizen with a grievance may come to have inordinate power over the fate of the nation, power she would never have at the ballot box. On minoritarian risk, see infra text accompanying note 134 .

82. See infra text accompanying notes 129-37 (discussing majoritarian and minoritarian risk).

83. I do not mean by this the standard realist claim of politics influencing law. I mean that no judge will be able to ignore the fact that one of the litigants before the court is the President and might well react in ways that are unique to the position of a sitting President. The judge might, for example, be influenced to rule against the plaintiff because of concerns about how the ruling would affect the nation. He might, on the other hand, defiantly rule against the President to insist on the "independence" of the judiciary, despite doubts about the viability of the claim. 
rejecting such politics too strenuously or in coddling it too nervously. And if the judge rules for or against the President or Jones because of majoritarian concerns, rather than the demands of the lawsuit, one can hardly call this "the rule of law."

\section{B. Morrison v. Olson: Will Congress's Role Please Step Forward?}

If Jones presents us with ways in which to see the vertical approach in operation, it may also point toward new ways of seeing old separation of powers dilemmas. Morrison v. Olson, ${ }^{84}$ the IC case, presents difficult questions for the Court's future approach in separation of powers cases (even though the IC statute has not been renewed). To many, today, in light of concerns about Kenneth Starr's IC investigation, ${ }^{85}$ it seems difficult to accept the majority's conclusion that the statute $^{86}$ did not "unduly trammel[] on executive authority." ${ }^{87}$ At the same time, although many have come to newly admire Justice Scalia's dissent in Morrison, ${ }^{88}$ few are willing to accept the implications of its formalism ${ }^{89}$ - that independent agencies are unconstitutional..$^{90}$

The vertical approach may, however, provide some clues about what went wrong in Morrison-how functionalism could have turned out to be so unrealistic despite its contrary pretensions, ${ }^{91}$ and yet how the dissent's formalism failed to cure this problem. Morrison is tradi-

Once the President has left office these risks will tend to decrease precisely because his relationship to the people has been severed.

84. 487 U.S. 654 (1988).

85. The public's once-held confidence in the "white knight" of independence has been replaced with a concern that the IC may become a rogue figure, vindictive, wasteful, and selfserving. This is especially troubling when individual lives and careers are at stake. See, e.g., Robert Dreyfuss, Collateral Damage: The Personal Costs of Starr's Investigation, NATiON, July 27, 1998, at 11; Lawrence M. O'Rourke, Many Lawmakers Targeting Independent Counsel Law, SACRAMENTO BEE, Feb. 16, 1998, at A17.

86. 28 U.S.C. $\$ \S 591-99$ (1994).

87. Morrison, 487 U.S. at 691 ; see also id. at 693 ("The final question to be addressed is whether the Act, taken as a whole, violates the principle of separation of powers by unduly interfering with the role of the Executive Branch.”).

88. An "independent" counsel simply will not do, urges Justice Scalia, for the President must have power over all executive functions-there can be no "independent" officer within the executive department. See id. at 705 (Scalia, J., dissenting).

89. Id. ("To repeat, Article II, $\S 1$, cl. 1 of the Constitution provides: 'The executive Power shall be vested in a President of the United States.' As I described at the outset of this opinion, this does not mean some of the executive power, but all of the executive power.").

90. This latter concern about the status of independent agencies may well work to give life to the separation of powers problems raised in Morrison, whatever the future status of the IC statute.

91. See supra note 28 (discussing the relationship of functionalism to realism). 
tionally perceived as a case about executive power and the constitutionality of independent executive agents. ${ }^{92}$ As I explain more fully below, there were other important issues left unaddressed in Morrison. From a vertical perspective, Morrison raises questions about the relationship of the IC not only to the President but also to the Congress. Indeed, the vertical approach suggests that both the majority and dissent in Morrison may well have been trying to answer the wrong question by focusing so heavily on questions of removal. ${ }^{93} \mathrm{In}$ the end, the most serious issue Morrison poses may not be about the status of independent agencies or the unitary executive but about whether the statute permits Congress and the President to sever from the people, even in small part, their power to choose their own government.

Consider a statute in which Congress delegated part of its impeachment authority to an independent agent. The problem with this proposal would not depend upon the independence of the agent alone, but upon the fact that an agent, with no constituency, is deciding the ultimate constituency issue in a republic-the political fate of a sitting President. The committed functionalist would no doubt argue that a partial delegation of the impeachment power does not interfere with the functioning of the executive or the Congress. But such an approach betrays the oddity of the conventional functionalists' realism. Perhaps a partial delegation of a function seems to matter little in the abstract, but, in real life, it may matter quite a good deal. Indeed, it is precisely because it would matter to the people that many would find it quite unconstitutional for Congress to hand over its impeachment authority to an independent entity; in such a world, "we the people" do not decide who governs but, instead, "we the investigating authority" decides. The constitutional risk of elitism is obvious: that a willful bureaucrat will investigate and prompt the removal of a President that the nation does not really want removed.

92. See Harold J. Krent, Symposium on Morrison v. Olson: Addressing the Constitutionality of the Independent Counsel Statute-Executive Control over Criminal Law Enforcement: Some Lessons from History, 38 AM. U. L. REV. 275, $277-78$ (1989) (critiquing the Supreme Court's assumption in Morrison that criminal law enforcement is an inherently "executive" function); see also Carter, supra note 23, at 106 (considering whether Morrison serves to legitimate a scheme of government that includes independent agencies).

93. For an argument about why "good faith" removal provisions may not be a particular concern, even if congressional control over appointment and removal is an important separation of powers issue, see Nourse, supra note 10, at 514-18. See also Richard H. Pildes \& Cass R. Sunstein, Reinventing the Regulatory State, 62 U. CHI. L. REV. 1, 29-30 (1995) (suggesting that the "good faith" removal question might be resolved in some cases by statutory construction). 
I am not arguing that the IC statute should have been held unconstitutional because the statute delegated Congress's power to impeach the President. But I am arguing that the IC is not a standard "independent agent," raising only questions analogous to those raised by the status of the Federal Trade Commission or the Nuclear Regulatory Commission. The important point here, lost in the Court's focus on executive power and removal, is the degree to which the IC statute shifts constituencies on the question of executive misconduct and impeachment and, as a result, creates significant incentives for majority will to be thwarted. Traditionally, Congress (and its state and local audiences) is responsible for policing presidential misconduct; the Constitution itself seals this by granting the impeachment power to the House initially ${ }^{94}$ and then to the Senate. ${ }^{95}$ The statute not only permits the IC to investigate and prosecute the President but also requires the IC to inform the Congress of grounds for impeachment. ${ }^{96}$ As Julie O'Sullivan has noted, "[t]his mandatory impeachment referral provision arguably makes impeachment proceedings far more likely to be initiated, and when initiated, far more threatening to the administration," because it may allow "an IC to control the timing, scope, and content of impeachment inquiries." ${ }^{97}$ The IC statute thus shifts at least some of the responsibilities ordinarily committed to the Congress to an official who is not only independent of the President but also independent of the Congress, and whose incentives may dispose him toward, rather than against, impeachment. ${ }^{98}$

At the same time as the IC statute shifts power away from Congress, it also shifts important powers to Congress. Traditionally, the power to prosecute is remitted to the executive department, not to

94. See U.S. CONST. art. I, § 2, cl. 5 .

95. See id. art. I, § 3, cls. 6-7.

96. See 28 U.S.C. $\$ \$ 591,594$ (1994) (authorizing the IC to institute civil or criminal proceedings against the President); id. § 595(c) ("An independent counsel shall advise the House of Representatives of any substantial and credible information which such independent counsel receives ... that may constitute grounds for an impeachment.").

97. Julie R. O'Sullivan, The Interaction Between Impeachment and the Independent Counsel Statute, 86 GEO. L.J. 2193, 2195 (1998).

98. See Sunstein, Bad Incentives, supra note 15, at 2279. Professor Sunstein notes the ways in which the IC statute creates incentives toward zealotry: "An independent counsel who uncovers nothing is likely to look as if he has more or less wasted his time, or done nothing, whereas an independent counsel who brings a prosecution, or several prosecutions, is likely to look, in at least some circles, like another Archibald Cox, a kind of hero of democratic ideals." Id. 
the Congress. ${ }^{99}$ However, under the IC statute, the decision to prosecute is granted, in part, to members of Congress. The statute specifically contemplates that " $[\mathrm{t}]$ he Committee on the Judiciary of either House of the Congress, or a majority of majority party members or a majority of all non-majority party members of either such committee, may request in writing that the Attorney General apply for the appointment of an independent counsel." ${ }^{100}$ That application must identify the persons and subject of the proposed investigation. The mere power to identify misconduct and its targets surely increases Congress's power, and the power of particular members of Congress, to target individuals relative to the powers Congress would have without the IC statute. Indeed, there is no greater power of a prosecutor than to decide the targets of an investigation and potential prosecution. ${ }^{101}$

A functional approach might tell us that, since this exercise of congressional authority does not undermine the prosecutorial function in general, it is permissible. A vertical approach, however, suggests that this should be constitutionally controversial. The Constitution grants no power to Congress to prosecute criminal behavior; indeed the Constitution bars bills of attainder explicitly. ${ }^{102}$ There is a good reason for this bar: the incentives of congressional leaders to punish the politically unpopular or simply their political enemies. Those very same risks inhere in the IC statute. By granting members of Congress the power to target individuals, and without substantial room for the Attorney General to reject investigations, ${ }^{103}$ the IC statute clearly creates incentives to politicize the decision of whom to

99. Even if there is doubt about whether prosecution has always constituted an executive function, see Krent, supra note 92, at 290, there is little doubt that Congress has no power itself to prosecute and punish individuals (outside of removal from office).

100. 28 U.S.C. $\$ 592(\mathrm{~g})(1)(1994)$.

101. See, e.g., Frank Remington, The Decision to Charge, the Decision to Convict on a Plea of Guilty, and the Impact of Sentence Structure on Prosecutorial Practices, in DISCRETION IN CRIMINAL JustiCE 73, 98 (Lloyd E. Ohlin \& Frank J. Remington eds., 1993) (asserting that "the charging decision is ... the single most important decision made in an individual case").

102. See U.S. CONST. art. I, § 9, cl. 3 ("No Bill of Attainder or ex post facto Law shall be passed."); see also Cummings v. Missouri, 71 U.S. (4 Wall.) 277, 323 (1866) (defining a bill of attainder as a "legislative act which inflicts punishment without a judicial trial").

103. See 28 U.S.C. $\S 592$ (b)(1) (providing that the Attorney General may only refuse to appoint an IC if she finds "no reasonable grounds to believe that further investigation is warranted"); see also James P. Fleissner, The Future of the Independent Counsel Statute: Confronting the Dilemma of Allocating the Power of Prosecutorial Discretion, 49 MERCER L. REV. 427, 434 (1998) (noting that the "triggering mechanism" for appointment of an IC is a "very low threshold" and that "the statute's formula is a recipe for referral"). 
prosecute. ${ }^{104}$ And those incentives are likely to be greater than if the decision rested in the hands of a career prosecutor. This is precisely because the political incentives of members of Congress, with their smaller and more local audiences, are likely to be stronger than those of a federal prosecutor, whose political incentives are dispersed across a national constituency, a broad range of prosecutions, and are limited by scarce resources. In shifting a decision from a relatively less to a more local political audience, the IC statute increases risks to minorities and individuals-risks that the decision to prosecute may depend upon the political whims not only of Congress, but of a few minority members of a congressional committee. ${ }^{105}$

To summarize, the IC statute poses two distinct structural risksseparate and apart from the traditional question the statute raises about independent agents and the unitary executive. ${ }^{106}$ Shifting influence over the question of impeachment from state and local constituencies to an actor without constituency (i.e., the IC) takes a very public, political act and hands it, in part, to an actor without public constituency. The second risk in Morrison raises a very different is-

104. It has not gone unnoticed that the statute risks unfairness to individuals. See e.g., Morrison v. Olson, 487 U.S. 654, 727 (1988) (Scalia, J., dissenting) (considering the effect of the statute upon the fairness of the process). However, this is usually phrased as a question of equal treatment, not a question about the role of Congress in the decision to prosecute. See, e.g., Fleissner, supra note 103, at 433 (arguing that the statute "creates the risk of subjecting those investigated to a different level of scrutiny and pursuit than an ordinary citizen might face"). Congress has indeed attempted to respond to the "unfairness" problem in directing IC investigations to look more like DOJ investigations. It did not, however, give up its role in prompting the investigations. See Julie O'Sullivan, The Independent Counsel Statute: Bad Law, Bad Policy, 33 AM. CRIM. L. REV. 463, 469-70 (1996).

105. For how an informational cascade may generate such a call, even in cases supported originally by few members of Congress, see Sunstein, Bad Incentives, supra note 15, at 2276-77.

106. In this regard, it is important to remember that the IC is not a standard independent agent. Independent agents within the executive department may be tied to the President through various means. The President can, as an organizational matter, subject them to some policy and budget control; indeed, it is possible that independent agents may even be fired if the statutory term "neglect of duty" "allow[s] some scope for construction." Pildes \& Sunstein, supra note 93, at 28-31. None of these safeguards applies to the IC: the IC's budget is not controllable by the President, see O'Sullivan, supra note 104, at 467; the Attorney General's supervisory authority is limited, see Fleissner, supra note 103, at 434; and even the Attorney General cannot, in the end, feel free to fire the IC, see 28 U.S.C. § 596(a). It inevitably brings with it the specter of confession, as President Nixon's "Saturday Night" massacre so clearly attests. See, e.g., Frank Tuerkheimer, Watergate as History, 1990 WIS. L. REV. 1323 (reviewing STANLEY I. KUTLER, THE WARS OF WATERGATE: THE LAST CRISIS OF RICHARD NIXON (1990)); see also Sunstein, Bad Incentives, supra note 15, at 2274 ("An Attorney General who discharged an independent counsel, or attempted to control an independent counsel's operations, would face enormous political pressure, and any Attorney General will know this.”). 
sue-risk not to the public but to individuals. Shifting part of the decision to prosecute from the executive to the Congress increases the risks that individuals will be targeted for their politics, not their crimes. Events have suggested that both of these risks were more real than anticipated either by Morrison's dissenting or majority opinions.

\section{The Federalism Cases: At the Intersection of Horizontal and Vertical Separation}

If the vertical approach may help us to understand the realism gap that has arisen between separation of powers doctrine and recent events, it might also have predicted the growing controversy about the Supreme Court's new federalism cases. Recently, the Supreme Court has decided several contentious cases-among them United States v. Lopez, ${ }^{107}$ Florida Prepaid Postsecondary Education Expense Board v. College Savings Bank, ${ }^{108}$ and City of Boerne v. Flores ${ }^{109}-$ arising under doctrines as various as the Commerce Clause, the Fourteenth Amendment, and sovereign immunity. In each of these cases, the Court has emphasized federalism concerns but has been less at pains to explain how the states' fundamental interests have been impaired than to outline how Congress has failed. In Lopez, the Court found that Congress had made no record of a substantial effect on commerce, ${ }^{110}$ in Florida Prepaid, the Court concluded that Congress had not amassed sufficient evidence of equal protection violations ${ }^{111}$ and in Boerne, the Court held that Congress could not "enforce" the Fourteenth Amendment if its proposed remedy would change the "constitutional right" at issue. ${ }^{12}$ Stripped of the complex doctrine generated by these cases, the real issue each raises is as much about federalism as it is about the relative strength of the Supreme Court and the Congress.

\footnotetext{
107. 514 U.S. 549 (1995).

108. 119 S. Ct. 2199 (1999).

109. 521 U.S. 507 (1997).

110. See Lopez, 514 U.S. at 563 ("[T] the extent that congressional findings would enable us to evaluate the legislative judgment that the activity in question substantially affected interstate commerce, even though no such substantial effect was visible to the naked eye, they are lacking here.") (footnote omitted).

111. See Florida Prepaid, 119 S. Ct. at 2208 ("[T]he legislative record still provides little support for the proposition that Congress sought to remedy a Fourteenth Amendment violation in enacting the Patent Remedy Act.”).

112. City of Boerne, 521 U.S. at 519 ("Congress does not enforce a constitutional right by changing what the right is.").
} 
It is generally thought that the doctrines of federalism and the separation of powers are quite distinct. But the vertical approach predicts that federalism and separation of powers concerns may intersect. We saw earlier, for example, that were we to eliminate the President's veto power, the resulting constitutional structure would not only decrease the power of the President relative to the Congress (a horizontal shift) but also increase the power of state and local constituencies (a vertical shift). ${ }^{113}$ Shifts at the horizontal level may thus affect shifts typically seen as vertical-the relative power of the state and national governments. Indeed, this is well known, although not often considered in this way. It is often complained, for example, that, if the Congress did not delegate so frequently to the executive branch our national government would not be as powerful as it is relative to the states. Perhaps more importantly, if this point were taken seriously, it should cause the Supreme Court to take greater pains in its separation of powers decisions to consider their federalism implications, a step that so far has only been hinted at by Justice Kennedy, from whom I have borrowed the term "vertical" separation of powers. $^{114}$

If horizontal shifts may cause vertical power arrangements to change, the opposite may be true as well: federalism questions (or shifts in vertical arrangements) may raise separation of powers concerns. The recent federalism cases make this quite clear. ${ }^{115}$ In an earlier era, the Supreme Court allowed Congress broad leeway to make

113. See supra text accompanying notes 55-57.

114. See Clinton v. New York, 524 U.S. 417, 452 (1998) (Kennedy, J., concurring) (noting that the "[s]eparation of powers operates on a vertical axis as well, between each branch and the citizens in whose interest powers must be exercised"). Kennedy's argument in the line-item veto case was that the veto gave the President too much power to "reward one group and punish another, to help one set of taxpayers and hurt another, to favor one State and ignore another." Id. at 451 .

115. In the Boerne decision, the Court specifically raised this point, urging that Congress had violated the separation of powers by exceeding its remedial powers under the 14th Amendment. See City of Boerne, 521 U.S. at 524, 536. Under a vertical approach, this conclusion of congressional aggrandizement is not obvious: had Congress sought to "decide" Religion Clause cases, we could certainly say that it had taken power from the courts. This was not, however, what Congress did under the Religious Freedom Restoration Act; Congress's big mistake here seems to have been its attempt to borrow language from the Supreme Court's own opinions and put it into a statute (language that the Court clearly had the right to ignore as a matter of constitutional law without maintaining that this borrowing somehow violated the separation of powers). See David Cole, The Value of Seeing Things Differently: Boerne v Flores and Congressional Enforcement of the Bill of Rights, 1997 SuP. CT. REV. 31, 41 ("RFRA provided a statutory right, not a constitutional right. It did not change the Constitution, but only the United States Code."). 
decisions about the relations between the states and the federal government under a variety of its powers. Now, the Court has significantly changed that status quo by restricting Congress's powers to abrogate sovereign immunity, to legislate under Section 5 of the Fourteenth Amendment, and to exercise its Commerce Clause powers. ${ }^{116}$ Even assuming that each of these decisions has a defensible basis, the question would still remain whether the Court should also consider the horizontal risks of these decisions. The vertical approach tells us that, in cases like Jones and Morrison, a shift to an unelected decisionmaker from one with direct constituency creates risks that political electorates will be silenced. So, too, may the federalism cases.

When a task is shifted from Congress to the courts, there is a shift from a national body with the relatively greatest incentives to be influenced by state and local political constituencies (i.e., Congress) to a national body that has no constituency and no such structural incentive (i.e., the courts). ${ }^{117}$ This creates risks that the voices of an aggregate of state and local constituencies will be silenced and indeed that an elite unelected body will act in their name. My point is not simply about the countermajoritarian risks of constitutional decisionmaking nor about the Wechslerian claim that Congress protects the states' interests. ${ }^{118}$ Congress may well forsake the states' interests, and it may do so on a regular basis. As a relative matter, however, it seems difficult to claim that the Senator from Illinois has fewer political ties to state officials and constituents than do the members of the Supreme Court. ${ }^{119}$ This does not mean that the Supreme Court cannot decide federalism matters without violating the separation of powers. I think it can and should. My point is that the federalism cases are also separation of powers cases. And, since they are separation of powers

116. See cases cited supra notes 107-09.

117. In indicating that there is a separation of powers risk, I am not asserting that the court is not permitted to take that risk or that the risk may not be justified by other protections or interests. I am saying that the risks should be considered in more than an offhand statement of deference to Congress or a confident assertion of the Court's right to assert what the Constitution says.

118. See Wechsler, supra note 59, at 558 .

119. Larry Kramer seems to me to be absolutely correct when he argues that political party structure provides the "glue" that often binds federal Senators and Representatives to state interests. See Larry Kramer, Understanding Federalism, 47 VAND. L. REV. 1485, 1491 (1994) (recounting how the constitutional structure has evolved to "link the political fortunes of state and federal officeholders - creating a mutual dependence that obliges politicians at each level to pay attention to politicians at the other"). 
cases, the Court must take into account not only structural concerns about the relationship of the states to their citizens but also the implications of its own decisions on the relationship between the Court and Congress.

There is no question that all the national departments have significant incentives to arrogate power to themselves and away from the states. There is also no question that this can create risks to minorities and individuals. The problem is that this is not the only risk. For if there is a risk to the liberty of individuals in failing to maintain federalism, there is also a risk to majorities (even state and local majorities) from a Court that seeks to protect its own prerogatives at Congress's expense. As Mark Tushnet has put it, "[i]f members of Congress have an incentive to maximize the sphere of their power and responsibilities, then so do Supreme Court justices with respect to their sphere." ${ }^{, 20}$ In cases in which Congress clearly has not considered the interests of the states, there is every reason for the Court to demand of Congress a deliberate effort to consider states' interests and federalism risks. When, however, Congress has considered the states' interests, and indeed when states support the national effort, the question becomes whether the Court's federalism decisions risk substituting an abstract and elitist vision of state autonomy for a real one.

The vertical approach predicts the ultimate irony here: the states themselves may end up paying for this judicial federalism. Indeed, there are risks that, when states impress themselves upon Congress and are effective in making their concerns known, the Court will ignore them. ${ }^{121}$ Time will tell whether the Supreme Court will address these concerns in its next round of federalism cases, but at least one currently pending case raises the distinct possibility that federalism will spell the demise of a statute that both Congress and a superma-

120. Mark Tushnet, Two Versions of Judicial Supremacy, 39 WM. \& MARY L. REV. 945, 949 (1998); see also id. at 950 (noting that "[t]hose who assume that the Court will act in good faith to enforce the Constitution seem, in this context, unwilling to assume that Congress will act in good faith"). Tushnet also points out that "[s]omehow Congress's power-maximizing interests are thought, not simply to operate in conjunction with, but to displace, its good faith," and he concludes that he "know[s] of no reason to adopt that assumption with respect to Congress but not with respect to the courts." Id.

121. My argument is not that the states may, for the sake of political whim, abrogate essential features of the relationship between the state and its citizens. The question always comes down to what federalism must mean, a meaning that I would argue must be considered in the light of the political incentives and risks involved, rather than some abstract "functional" distribution of powers. 
jority of states support as a proper exercise of cooperative federalism. $^{122}$

\section{CONSIDERING POLITICAL RELATIONSHIPS}

Applying a theory does not explain how it works. In this part, I explain why the separation of powers is, in the end, a question of who will govern-where "who" refers to the people gathered in constitutionally created constituencies. The separation of powers is, in this sense, not only a separation of constitutional duties, powers, or functions, but also a separation of political relationships between the government and the people. I first consider the reasons why a vertical approach might add greater realism to the analysis of structural risk. I explain the comparative nature of the proposal (with its focus on risk and structural incentive), consider its advantages over the current functional ideal, and respond to objections based on text, history, and pragmatism.

\section{A. Structure and Constituent Harms}

Lawyers revere the separation of powers as a constitutional ideal without ever really identifying the dangers that follow from structural change. ${ }^{123}$ Contemporary doctrine too often suggests that separation of powers violations produce a kind of transcendental harm-causing functions to be mixed, boundaries to be crossed, and balance to be disrupted. ${ }^{124}$ Few can tell you, for example, why any of these harms is

122. See United States v. Morrison, 120 S. Ct. 11 (1999) (granting certiorari). Amici curiae representing 36 states filed briefs arguing that the civil rights remedy in the Violence Against Women Act did not impinge on states' rights. See Linda Greenhouse, Justices Cool to Law Protecting Women, N.Y. TIMES, Jan. 12, 2000, at A18 (noting that an additional state, Alabama, had filed a brief on the other side).

123. Scholars have noted and criticized the Supreme Court for failing to identify the "values" upon which it is relying, see, e.g., Brown, supra note 24, at 1518 (bemoaning the fact that the Court has not taken a "stand on what values the structural provisions of the Constitution should promote"), even though scholars disagree among themselves about the appropriate "values." Compare id. (emphasizing the importance of due process and individual rights), with Flaherty, supra note 29 (emphasizing the importance of structural balance as essential to the Framers' understanding of separation), and with Cass R. Sunstein, Constitutionalism After the New Deal, 101 Harv. L. ReV. 421, 434-36 (1987) [hereinafter Sunstein, Constitutionalism] (listing a variety of policies informing the separation of powers, including the rule of law, limited government, and individual liberty).

124. See, e.g., Morrison v. Olson, 487 U.S. 654, 695 (1988) (reasoning that the IC does not "disrupt[] the proper balance" of power (quoting Nixon v. Administrator of Gen. Servs., 433 U.S. 425, 443 (1977))); Bowsher v. Synar, 478 U.S. 714, 779 (1985) (Blackmun, J., dissenting) (describing the majority's decision as holding that "the Comptroller General's functions under 
of importance in the real world. There are strong arguments that the Constitution itself mixes functions, ${ }^{125}$ enjoins the departments to cross boundaries, ${ }^{126}$ and grants too much power to some departments. ${ }^{127}$ In this world of canceling arguments and quotations, many have simply thrown up their hands and claimed that the separation of powers cannot be important. ${ }^{128}$

A vertical approach replies that the separation of powers is important, and it is important for this reason: the danger lies in shifting the incentives of those who govern in ways that may silence or amplify some popular voices at the expense of others. ${ }^{129}$ The question thus becomes one of who will wield authority and what risks and incentives that shift in decisionmaker entails for constitutional relationships between the people and their governors. Statutes may shift deci-

the ... Act were constitutionally incompatible with the . . removal provision" (emphasis added)); INS v. Chadha, 462 U.S. 919, 962 (1982) (stating that the boundaries of the departments are set by “"common sense and ... inherent necessities"” (quoting J.W. Hampton \& Co. v. United States, 276 U.S. 394, 406 (1928)).

125. For example, the power to name executive officers is generally conceived of as an executive power, yet the Constitution allocates this power to both the President and the Senate. See U.S. ConsT. art. II, § 2, cl. 2 ("He shall ... nominate, and by and with the Advice and Consent of the Senate ... all other Officers of the United States ...."). Similarly, the power to adjudicate is generally conceived of as a power held by the judiciary, yet the Senate adjudicates impeachment proceedings. See id. art. I, § 3, cl. 6 ("The Senate shall have the sole Power to try all Impeachments.").

126. The presidential veto is the classic check against legislative power. See id. art. I, § 7, cl. 2; see also THE Federalist No. 51, supra note 25, at 350 (referring to the Senate's role in appointing various executive officers as a "qualified" connection between the Senate and the President, bolstering the strength of the presidency vis-à-vis the Congress). For a sophisticated analysis of the checking theory, see Greene, supra note 24.

127. The Antifederalists believed, for example, that the President had far too much power, a sentiment that has been emphasized by a variety of others at different points in history. For a modern claim that the President is too powerful, see Flaherty, supra note 29, at 1727-29 (observing that the executive branch has never been more powerful than since the New Deal). For a critical analysis of this view of the presidency in general, see Michael Fitts, The Paradox of Power in the Modern State: Why a Unitary, Centralized Presidency May Not Exhibit Effective or Legitimate Leadership, 144 U. PA. L. REV. 827, 835-36 (1996) (arguing that claims of the imperial presidency overlook the ways in which a unitary executive actually makes the President a good bit weaker than he might otherwise seem).

128. See, e.g., Lloyd N. Cutler, Some Reflections About Divided Government, 18 PRESIDENTIAL STUD. Q. 485 (1988) (arguing that a parliamentary system shares power more effectively).

129. My use of the metaphor of voice and my emphasis on constituency should not be confused with the argument that voice is an end, rather than a means. Power is not conversation (even metaphorically); it entails real risks to real lives and to governmental structure. But see Laura S. Fitzgerald, Cadenced Power: The Kinetic Constitution, 46 DuKE L.J. 679 passim (1997) (characterizing the power of the constitutional constituencies as the power of argument and "conversation"). 
sionmaking from smaller to larger constituencies or from larger to smaller ones; they may shift a decision from no constituency at all to the most local of constituencies. In these shifts, we can see relative changes in political incentives and thus increases or decreases in structural risk. The incentives and risks here are to a "form" of government-whether the government will be more inclined to veer toward rule by the few or by the many. Moving a governmental decision to a more politically independent body, for example, may increase decisionmakers' incentives toward elitist solutions (rule by the few at the expense of the many). ${ }^{130}$ Moving in the opposite direction, to a more politically dependent body, may decrease decisionmakers' incentives toward elitism, but may increase incentives to oppress minorities (rule by the many at the expense of the few).

The importance of structural incentives and risks is not only evident from an understanding of constitutional text ${ }^{131}$ and history ${ }^{132}$ but also consistent with modern economic understandings of the dynamics of institutions. As Neil Komesar has discussed at length, there are two risks facing every institutional choice. ${ }^{133}$ The first risk is minoritarian in character-the risk that concentrated interests will gain at the expense of dispersed majorities. ${ }^{134}$ (I have also labeled this risk as the risk of rule by the "elite," in an effort to link it explicitly to a form of government and yet to emphasize that the evil sought to be avoided is that the few will prefer themselves over the many). The second, countervailing risk is majoritarian-that concentrated inter-

130. This is a rough approximation, but it seems fair to say that when Congress seeks to move its own decisions to an "independent" decisionmaker, for example, there are increased risks that the popular will may be thwarted. This risk applies regardless of whether the shift is to the IC or the Sentencing Commission; the separation of powers question then becomes whether the risk is offset by countervailing incentives or protections. See infra note 184 (discussing countervailing protections relied upon by the Schor Court to uphold the assignment of adjudicatory power to the Commodity Futures Trading Commission ("CFTC")).

131. See infra text accompanying notes 187-89.

132. See generally Nourse, supra note 10, passim (discussing The Federalist Papers). For my response to arguments that the vertical approach is not supported by history, see infra text accompanying notes 189-94.

133. See Komesar, supra note 15, at 65-82; see also Richard Pierce, Public Utility Regulatory Takings: Should the Judiciary Attempt to Police the Political Institutions?, 77 GEO. L.J. 2031, 2041-42 (1989) (following Komesar's two-force model of politics). Professor Komesar has developed this idea in a series of articles. See, e.g., Komesar, Job for Judges, supra note 53, at 66872 (discussing two notions of political malfunction).

134. See Komesar, Job for Judges, supra note 53, at 671 ("Minoritarian bias supposes an inordinate power of the few at the expense of the many."). 
ests will be victimized by powerful majorities. ${ }^{135}$ Catalyzed by subgroups capable of easy organization, majority interests in the political market can use voting to prefer themselves, oppressing unpopular individuals or minorities. ${ }^{136}$ (I have also labeled this risk as the risk of rule by the mob, again in an effort to link it to a form of government and yet to emphasize that the evil sought to be avoided is that the many will prefer themselves to the few).

\section{B. Shifting Constituencies: The Comparative Nature of Vertical Analysis}

For the vertical approach to work at all, it requires an explicitly comparative analysis. Simply because we move a decision from a larger to a smaller constituency does not mean that we will veer toward aristocracy, nor does it mean that the decisionmaker will, in fact, favor a particular constituency. It may mean (all other things being equal), a relative change in certain kinds of structural incentives. The further the decision is taken from the hands of political authority, the more insulated the decisionmaker is from politics, the risk of elitism increases (i.e., the risk that the decision will disregard the popular will), but the risk of oppression decreases (i.e. the risk that the decision will disregard minority interests). By contrast, the greater the move toward political authority and away from independence, the risk of elitism decreases, and the risk to individual or minority rights increases. ${ }^{137}$

On one level, this kind of analysis is very well known ${ }^{138}$ and yet, on another it is elusive. We have known, and many have argued, that

135. See id. at 672 ("Majoritarian bias can be defined as an opposite response to the same skewed distribution of impacts which characterized minoritarian bias.").

136. See id. at 668 ("Two visions of political malfunction-one stressing fear of the many and the other stressing fear of the few-coexist in our traditional views of government.... [B]oth conceptions are viable representations of serious political malfunction applicable to different but important instances of political decisionmaking."); see also Neil K. Komesar, Paths of Influence-Beard Revisited, 56 GEO. WASH. L. REV. 124, 126 (1987) ("One conception emphasizes the undue influence of the many to the detriment of the few (majoritarian bias); the other emphasizes the undue influence of the few to the detriment of the many (minoritarian bias).").

137. Thus, as a general, albeit highly simplified, rule, shifts from the President or the Congress to the courts increase risks of elitism but decrease risks of oppression. Shifts in the opposite direction, from the courts to the President or to Congress, increase the risks of oppression but decrease the risks of elitism. These risks, it is important to note, are neither isolated nor exclusive. It is possible to have a case, for example, in which shifting constituencies increases the risks of oppression and elitism. See supra text accompanying note 106 (discussing the IC case).

138. My version of political risk differs from much legal theory only to the extent that it does not single out a particular kind of political malfunction, majoritarian or minoritarian bias, 
individual rights are at issue in separation of powers cases. ${ }^{139}$ We have also known that accountability figures in separation of powers cases. What a vertical approach adds is that these are not simply static values, but a reflection of shifting political relationships, that these risks are relative, and that they may be linked. Accountability arguments fail to distinguish between accountable decisionmakers: members of Congress and the President do not represent the same constituencies and therefore are not responsive in the same ways. Accountability arguments also fail to account for countervailing risks-that more accountability may mean greater risk to individuals. ${ }^{140}$ Similarly, individual rights arguments often fail to grant any ground to shifting structural concerns and to recognize that solutions protecting individual rights may end up sacrificing majority will.

The vertical approach rejects the hope of formalists and functionalists alike that we can arrive at a settled vision of the ideal departmental structure and work from there to evaluate shifts in power. It is explicitly and designedly a "transition argument" looking at shifts in power, not a final end state of affairs or a departmental essence. ${ }^{141}$ Such arguments are "inherently comparative." 142 There has been too much ink spilled on whether a particular function really is executive, on what is the meaning of the Vesting Clauses, and on which quotation from Madison is really the better one. The vertical approach explicitly seeks to make the analysis more modest and yet more grounded by analyzing how a shift in decisionmakers changes governors' incentives. ${ }^{143}$ My claim is not that the vertical approach is "true,"

but considers both. See KOMESAR, supra note 15, at 213-15; see id. at 214 ("Minoritarian bias is as serious systemic political malfunction as is majoritarian bias. In both instances, important interests are unrepresented."); $c f$. JOHN HART ELY, DEMOCRACY AND DISTRUST: A THEORY OF JUDICIAL REVIEW, ch. 4 (1980) (focusing on the risks of what I would call oppression-that minorities will not be represented in the political process and, therefore, should be "virtually represented" by the courts).

139. The leading scholar on this position is Rebecca Brown. See Brown, supra note 24.

140. Compare Harold H. Bruff, On the Constitutional Status of the Administrative Agencies, 36 AM. U. L. REV. 491, 506-08 (1987) (arguing that clarity of political accountability may justify decisions such as Chadha and Bowsher), with Flaherty, supra note 29, at 1834-36 (rejecting the notion that accountability requires results like those in Bowsher and Chadha).

141. See Charles Taylor, Philosophical Arguments 54 (1995):

A foundational argument to the effect that $\mathrm{Y}$ is the correct thesis shows its superiority over the incompatible thesis $\mathrm{X}$ only incidentally .... It is crucial to transition arguments that they make a more modest claim. They are inherently comparative. The claim is not that $\mathrm{Y}$ is correct simpliciter but just that whatever is 'ultimately true,' $\mathrm{Y}$ is better than X. It is, one might say, less false.

142. Id. 
as much as that it simply is a better proxy than functional description for assessing structural risk. ${ }^{144}$

As Charles Black told us, political relationship drives constitutional power and practice. The House member from the Twenty-fifth district of Texas "lives and dies [based] on what they think of him in the Twenty-fifth Texas." ${ }^{145}$ The vertical analysis assumes that there is a relatively greater risk that the member of the Twenty-fifth District will focus on his smaller constituency's desires than that the President or the courts will focus on the parochial desires of the Twenty-fifth. This claim should not be controversial as a relative matter, but it should be remembered that it is a relative matter. The member from the Twenty-fifth will not always represent only the Twenty-fifth, and the President may under some circumstances sacrifice other interests to protect the Twenty-fifth. However, from the perspective of structural incentive, the member from the Twenty-fifth poses a more likely risk, relative to the President, that he will favor the interests of the Twenty-fifth.

For some, no doubt, this will create confusion and suggest cynicism. Does not the member from the Twenty-fifth have a duty to the nation as well, she will ask? Of course, but the vertical approach does not urge to the contrary. To say that the member from the Twentyfifth derives his political authority from the Twenty-fifth does not mean that he may aid and abet Abu Nidal. It is to say that he has no constitutional authority to cast the votes of the citizens of the Third District of Massachusetts or those of the President. That the member from the Twenty-fifth has overlapping constitutional obligations does not change his constitutionally prescribed constituency; his oath of office cannot make the member from the Twenty-fifth into the President or the Congress or the Senator from the state of Alaska. Only a change in the Constitution or his constituency can do that.

\footnotetext{
143. The skeptic might argue, for example, that if I am looking for shifting power, I must start somewhere to determine that shift. Indeed, I must start with a baseline. Admittedly, and purposefully, I begin from what I take to be an uncontroversial status quo. Errors, of course, might be made at the start although these may be reduced to the extent my analysis contemplates that one should acknowledge doubts about characterization at the start. See infra text accompanying note 167 .

144. For an argument that current "functional" approaches are not as good a proxy, see infra Part III.C.

145. Charles L. Black, Jr., The Working Balance of the American Political Departments, 1 HASTINGS CONST. L.Q. 13, 16-17 (1974).
} 
Put another way, my argument is not about representation as a fact, but representation as an incentive and as a political principle. To say that a shift from one institution to another shifts political constituencies is not a claim that those constituencies will actually be heard or that they will not be betrayed. I am not arguing, nor do I believe, that the President always responds to the nation's will any more than members of Congress always bow to the desires of their districts or states. The vertical approach does not require, however, that representatives receive accolades for their representation-it simply provides us a sense of the likely stakes and incentives of structural change. The vertical approach assumes that political officials have a structural incentive to be parochial and that they will speak to and be influenced by their constituents in making their decisions. ${ }^{146}$ That assumption reflects the purpose of structural protections. If men were angels, we would need none. ${ }^{147}$ At the same time, assessment of structural risk cannot solve every problem of constitutional representation. If representatives betray their constituents' true interests on any particular issue, ${ }^{148}$ there is little that the separation of powers can do to

146. The notion that representatives respond to the interests that will reelect them is a staple of much legal theory and political science. See, e.g., RiCHARD F. FENNO, JR., HOME STYLE: HOUSE MEMBERS IN THEIR DISTRICTS 8 (1978) (emphasizing members' reelection constituency); John W. Kingdon, Congressmen's Voting DeCisions 17 (1989) (emphasizing the influences of constituents and colleagues on voting decisions); Black, supra note 145, at 16-17; Bruff, supra note 140, at 508 ("The political responsibility of members of Congress is mostly individual.... [and] the record of individual actions certainly dominates reelection campaigns."). There are, of course, competing theories—economic and institutional-about the reasons for political action. My claim is only the minimal one that few members do or should vote without regard to, or against, the interests of those they represent. See HANNAH FENICHEL PITKIN, THE CONCEPT OF REPRESENTATION 166 (1967) ("The representative must act in such a way that, although he is independent, and his constituents are capable of action and judgment, no conflict arises between them. He must act in their interest, and this means that he must not normally come into conflict with their wishes.").

147. See The FedERALIST No. 51, supra note 25, at 1 ("If men were angels, no government would be necessary. If angels were to govern men, neither external nor internal controuls on government would be necessary."). On the Humean resonance, see Nourse, supra note 10, at 480 ("Making Humean 'bad men ... a act for the public good' is precisely the goal of Madison's 'policy of supplying by opposite and rival interests, the defect of better motives."'(footnotes omitted)). Even those committed to the republican ideal recognize, I believe rightly, that the Framers sought, in structure, an "auxiliary protection," in case men did not act with virtue. See Michael J. Sandel, Democracy's Discontent: America in Search of A Public PHILOSOPHY 129 (1996) (“[T]he Constitution did not seek to elevate the moral character of the people.... Instead, it sought institutional devices that would save the republican government by making it less dependent on the virtue of the people.").

148. See Michael J. Klarman, Majoritarian Judicial Review: The Entrenchment Problem, 85 GEO. L.J. 491 passim (1997) (arguing that judicial review may serve majoritarian purposes where representatives act contrary to the preferences of their constituents). That representation 
rectify that; all that the separation of powers can achieve is to reduce particular structural incentives, not all political risks.

\section{The Silent Demands of the Functional Ideal}

Even with these caveats, the question still remains whether such a vertical approach really works. There is reason to believe, for example, that the inquiry can be quite complex. Cases may involve more than one risk-of majoritarian and minoritarian bias. ${ }^{149}$ Similarly, identification of the risks is only the first step in the process. One must still ask if the structural scheme as a whole creates a substantial risk unmitigated by other structural features. ${ }^{150}$ The skeptic will ask, of course, whether, given the difficulties, the project is worth the candle.

It would be enough, I believe, if the vertical approach helped us to see with greater clarity the connection between shifting power and constitutional harm. But, if the reader has gotten this far, she also knows that I believe that this kind of inquiry merits attention on other accounts as well. Unlike conventional approaches, vertical analysis does not commit us to an ideal that keeps us, as current approaches do, lurching from claims that no governmental innovation is possible to claims that all innovation is permissible. ${ }^{151}$ It does not obscure important shifts in political power, deny the individual nature of the departments, ${ }^{152}$ or aspire to a constitutional unity that is overstated or false. ${ }^{153}$ It is republican ${ }^{154}$ and, at the same time, does not depend upon

creates other kinds of governmental risks does not undermine my claim that risks of elitism and oppression are those that structure seeks most obviously to protect against-it simply suggests that there may be other ways in which we might want to correct for representational failure.

149. See supra Part II (discussing Morrison and Jones).

150. For example, as I argue below, the Supreme Court's decision in Schor is a case in which the Court found the risk of increased politicization to be minimal relative to the available protections. See infra notes 177, 184.

151. I am referring here to the fact that conventional theoretical views tend to lead to results rather than rationales. See Tushnet, supra note 27, at 584 ("Formalist opinions almost invariably strike down legislation; functional opinions almost invariably uphold it.").

152. See infra text accompanying note 174 (arguing that conventional approaches mistakenly treat the departments as fungible).

153. See supra notes 35, 125 (arguing that the Constitution itself does not provide functionally unified departments).

154. To say that this theory is republican is simply to say that we have a government that mediates popular desire through representation. See PITKIN, supra note 146, at 194 (describing Madison's position that in a republic, unlike a democracy, "there is representation: government is delegated to a few men by the rest"). 
civic virtue or altruistic regard for others. ${ }^{155}$ It is textual, yet at the same time, it avoids the literalism demanded by those who believe the only important text to be the terms "executive," "legislative," and "judicial." ${ }^{156}$ It is grounded in the realism of political practice, but a realism that is more than simply deference to the momentary wisdom of political majorities. ${ }^{157}$ Most importantly, however, it does not ask us to embrace a theory of political power that rejects the ultimate sovereignty of the people.

The vertical approach may not be ideal, but it is, I believe, better than functional analysis alone. It is a better proxy for what function aims to mirror. Functional analysis aims to maintain constancy of structure, to avoid the risks of which I have written, but it aims to do so by imposing labels that the Constitution itself defies. In the end, the problem with functional analysis is its failure to recognize that "function" is a proxy for a whole set of constitutional features that the approach aims to link by ever more general descriptions. In a sense, we might have known this-it seems very odd that a set of three words-executive, legislative, and judicial-could ever come to comprehend the rest of the Constitution. The results of this effort, perhaps predictably, risk begging the question, ${ }^{158}$ undermining the project, $^{159}$ and rendering Supreme Court case law hopelessly irreconcilable. ${ }^{160}$

Conventional approaches tell us, for example, that we cannot decide separation of powers cases without labeling the innovation or the departments as executive, judicial, or legislative. ${ }^{161}$ The very form of the inquiry seems to beg the question: "function-talk" suggests, in advance, that there is some conceptual unity in functional description,

155. See GeOffrey R. StOne ET AL., Constitutional LAW 5 (1991) (equating early republican arguments with "civic virtue-the willingness of citizens to subordinate their private interests to the general good"). My analysis proceeds on the more desperate, but realistic, assumption of Madison (who borrowed it from Hume) that structure is best protected by assuming that those who govern are far from "angels."

156. For a discussion of the textual argument, see infra text accompanying notes 187-89.

157. See infra text accompanying note 197 (arguing that those who seek to defer to political voices on structural questions do not abstain from, but participate in, politics).

158. See infra text accompanying notes 161-64 (discussing how conventional approaches assume functional unity).

159. See infra text accompanying notes 161-68 (discussing how the functional aim to describe the departments undercuts its critical ambitions).

160. See infra text accompanying notes 174-87 (discussing how the Bowsher case and the Schor case may simply raise different risks).

161. See supra text accompanying notes 17-36 (discussing how conventional approaches are committed to the functional ideal). 
however roughly defined. Right at the start, we become tacitly committed to the idea that something needs to be justified about a governmental process that involves more than one function or appears to cross functional boundaries-even though the Constitution itself defies this ideal. ${ }^{162}$ It is no wonder that we have ended up talking about the "unity" of the departments, since the very assumption that the departments are functions seems to presuppose the possibility of such a unity. ${ }^{163}$ It is also no wonder that the Supreme Court has never had the will to impose such a vision: if all the powers of the executive must be executive, does the President's veto become unconstitutional?

Because traditional approaches trade on the categorical, they also fail by the categorical. Panic erupts when a governmental innovation does not fit within the borders of a particular department-when the legislative veto may be described in more than one way, ${ }^{164}$ when the Sentencing Commission seems to be heir to the powers of both judges and legislators, ${ }^{165}$ when the Comptroller General is tied to the Congress but performs something that looks like execution. ${ }^{166} \mathrm{Un}$ bound by metaphors implicitly demanding that a power cannot be in two places or perform two functions at the same time, the vertical approach allows us to assess what contemporary departmental metaphors suggest is inherently impossible-overlapping risks. Indeed, in cases like Morrison, we can see quite clearly that there is more than one risk at stake-that there are risks both of elitism and of oppression, to individual rights and to majority will.

Vertical analysis thus gives us a way to examine structural risk without getting bollixed up at the beginning in questions about the

162. See supra notes 35,125 (discussing the ways in which the Constitution violates the functional ideal).

163. Indeed, much scholarly work in the past decade has tended to focus on, or to respond to, the notion of a "unitary" executive. See, e.g., Stephen G. Calabresi, Some Normative Arguments for the Unitary Executive, 48 ARK. L. REV. 23, 36-37 (1995) (concluding that the current governmental situation "virtually mandates the creation of a much stronger and more unitary presidency"); Calabresi \& Rhodes, supra note 31, passim (arguing for a unitary executive theory). But cf. Lessig \& Sunstein, supra note 25, at 118-19 (arguing that the historical evidence does not support a unitary executive theory but that it may be an appropriate "translation" of the historical record).

164. See supra note 21 (noting the dispute within the Supreme Court about how to characterize the legislative veto); see also supra note 36 (discussing other categorization disputes among the Justices).

165. See Mistretta v. United States, 488 U.S. 361, 383-84 (1989).

166. See Bowsher v. Synar, 478 U.S. 714, 717-21, 726 (1986). 
inherent incompatibility of multifunctionalism. Political relationships may change, overlap, and create risks without requiring, in advance, that the danger lie in the very concept we are using to solve the problem. For example, a case like Mistretta may be analyzed without engaging in a frantic search for the "location" or the "function" of the Sentencing Commission. ${ }^{167}$ Since we are not searching for $a$ function or $a$ location, we may contemplate not a single risk, but multiple ones. We can consider that the Sentencing Commission was to be performing tasks typically undertaken by the legislature (raising questions about shifts from state and local constituencies to more independent ones), as well as by the courts (raising questions about risks running in the opposite direction from an independent body to one with relatively greater electoral ties). Indeed, we may even consider that the statute shifted power from the Congress to individual federal prosecutors potentially raising risks of both oppression and elitism.

If this is right, it may help to free us from the all-or-nothing positions suggested by contemporary doctrine. Vertical analysis specifically contemplates that some governmental innovations may be consistent with sound structural imperatives, while other innovations may not. Judgments will have to be made about the nature of the risks and about whether the statutory scheme protects adequately against those risks. In some cases, the risks to constituency may be clear. Few believe, for example, that the President should have the power to write specific districts or states out of the Constitution. At the same time, there may be cases where the risks to political voice are more formal than real. In cases like Commodity Futures Trading Commission v. Schor, ${ }^{168}$ for example, the Supreme Court found that various procedures (administrative law judge ("ALJ") insulation, appeal rights, etc.) reduced the risk of politicization inherent in shifting adjudication from the courts to an executive agency. ${ }^{169}$ This means, of course, that judgment calls will have to be made in applying such a theory. But in a world in which our major theoretical approaches are widely believed to be corrupt and result-oriented, ${ }^{170}$ it hardly seems a conclusive

\footnotetext{
167. See Mistretta, 488 U.S. at 384-86.

168. 478 U.S. 833 (1986).

169. See id. at 836 (noting that the "broad regulatory powers of the CEA were most appropriately vested in an agency which would be relatively immune from the 'political winds that sweep Washington'” (quoting H.R. REP. No. 93-975, at 44, 70 (1974))); see also id. at 855-56 (discussing the decision by Congress to grant the CFTC jurisdiction over CEA claims because of its perceived immunity from political pressures).

170. See, e.g., Elliott, supra note 22, at 512; Tushnet, supra note 27, at 584.
} 
argument that there may be some uncertainty involved. No nontrivial theory is free from judgment calls. ${ }^{171}$ The best that we can ask is that, at the very least, we are asking better questions, questions that do not invite particular answers from the start.

Because the vertical analysis breaks through some of the metaphorical commitments of conventional approaches, it allows us to see issues that conventional theory tends to obscure. Indeed, the vertical approach allows us to see shifts in power that are virtually impossible to see from the perspective of conventional approaches to the separation of powers. Typically, courts see shifts in power as "contestable"-as questions of the separation of powers-when there appears to be "mixing" involved, when a "location" has shifted, or when a department acquires a new "function." " It is rare that a court even considers the possibility that shifts in power may occur by means other than a reassignment of legal authority. But, as my hypothetical constitution makes quite clear, shifts in power may be accomplished by other means. For example, changing the mode of appointing personnel who make governmental decisions may accomplish rather dramatic shifts in political power. ${ }^{173}$

Conventional theory tends to obscure such shifts because it assumes departmental fungibility. If one is worried about mismatched functions or crossed boundaries, then there is no relevant difference between granting executive authority to the Congress or legislative authority to the courts-both arrangements improperly mix powers or functions. Conventional theory thus assumes that the departments are the same thing- cogs in the great constitutional machine or places on a constitutional geography. Vertical analysis proceeds upon precisely the opposite assumption-it assumes that the departments are different because they represent different constituencies. As a result, a shift from the Congress to the courts does not necessarily pose the same risks as a shift from the President to Congress.

Once this is understood, it is also possible to see that the conventional academic analysis of the Supreme Court's cases may have actually helped to create the "mess" that academics condemn. ${ }^{174}$ Cases that seem to present inherent inconsistencies may simply turn out to

171. See ELY, supra note 138, at 62 .

172. See Mistretta v. United States, 488 U.S. 361, $383-86$ (1989).

173. See supra text accompanying notes 61-67 (discussing the potential of a proposal that would permit Congress to appoint executive officers).

174. On the "mess" characterization, see supra note 23. 
be "different." Consider the classic opposition in the literature between two cases, decided the same day, which appear to stand in stark, irreconcilable opposition. Commodity Futures Trading Commission v. Schor ${ }^{175}$ is widely known as an opinion that sits on the liberal, realist side of the separation of powers canon. ${ }^{176}$ At issue in Schor was whether an administrative agency could adjudicate claims. Finding no substantial interference with the function of the judiciary, the Court affirmed the arrangement. ${ }^{177}$ But on the same day, in Bowsher v. Synar, ${ }^{178}$ the Supreme Court, faced with a similar functional clash, applied a far more formal analysis ${ }^{179}$ and struck down the Gramm-Rudman-Hollings Budget Act, ${ }^{180}$ on the grounds that it improperly mixed executive and legislative powers.

From the perspective of function, Bowsher and Schor appear irreconcilable. ${ }^{181}$ In one, the Supreme Court affirms a functional mismatch between the executive and judiciary; in the other, the Court rejects a functional mismatch between a congressional officer and an executive function. From the vertical perspective, however, Bowsher

175. 478 U.S. 833 (1986).

176. See, e.g., Bruff, supra note 140, at 502-03 (contrasting Schor with various formalist cases); Verkuil, supra note 24, at 312 (noting that Schor employs a functional analysis). But cf. Peter E. Quint, Reflections on the Separation of Powers and Judicial Review at the End of the Reagan Era, 57 GeO. WASH. L. REV. 427, 445 n.74 (1989) (claiming that Schor's deferential attitude may have suggested flexibility only with respect to "Congress in its allocation of judicial power between Article III courts and other judicial or quasi-judicial agencies").

177. See Schor, 478 U.S. at 851-52 ("An examination of the relative allocation of powers between the CFTC and Article III courts in light of the considerations given prominence in our precedents demonstrates that the congressional scheme does not impermissibly intrude on the province of the judiciary.").

178. 478 U.S. 714 (1986)

179. Bowsher has become known as a rather formalistic opinion. See Suzanna Sherry, Separation of Powers: Asking a Different Question, 30 WM. \& MARY L. REv. 287, 292-93 (1987) ("The majority in Bowsher divided all possible governmental powers and government officers into three categories-legislative, executive, and judicial-and demanded a perfect match between the power and the officer. Each branch was required to be 'separate and wholly independent." (quoting Bowsher, 478 U.S. at 722)).

180. Balanced Budget and Emergency Deficit Control Act of 1985, Pub. L. No. 99-177, 99 Stat. 1038.

181. See Harold J. Krent, Separating the Strands in Separation of Powers Controversies, 74 VA. L. REV. 1253, 1255 (1988) (highlighting the "substantial inconsistency" between the Bowsher and the Schor approaches). Compare Schor, 478 U.S. at 851 (reasoning that applying "formalistic and unbending rules" to structural controversies may "unduly constrict Congress' ability to take needed and innovative action pursuant to its Article I powers"), with Bowsher, 478 U.S. at 736 ("“[T] he fact that a given law or procedure is efficient, convenient, and useful in facilitating functions of government, standing alone, will not save it if it is contrary to the Constitution."” (quoting I.N.S. v. Chadha, 462 U.S. 919, 944 (1983))). 
and Schor are simply different cases; indeed, they pose precisely the opposite risks. Bowsher involves a shift from a more to a less politically tied decisionmaker-from a budget decision made by the Congress and the President to a budget decision by an agent with no constituency. ${ }^{182}$ Schor involves a shift from a less to a more politically tied decisionmaker-from the judiciary to an ALJ within the executive department. $^{183}$

The vertical approach makes it clear that we need look not only at where power goes to, but also where it comes from. It is not enough, as some functional approaches suggest, simply to look at the department in which the decision ends. In both Bowsher and Schor, power seems to have been granted to relatively independent agents: the ALJ in Schor and the Comptroller General in Bowsher. But these independent agents gained decisionmaking authority from very different decisionmakers and that explains the difference in the relative risks presented by these cases. Shifting power from courts to ALJs raises a risk of increasing politicization. The risk is that the ALJ has relatively stronger incentives than a judge to follow the call of politics in deciding the case ${ }^{184}$ By contrast, Bowsher raises precisely the opposite risk: a risk of decreasing politicization. The budget act shifted power to decide budget matters from Congress to an independent agent and, in the process, cut the President out of any final budget decision. ${ }^{185}$ The shift in constituency in Bowsher moves from the most

182. The issue in Bowsher was whether the Comptroller General, an independent agent, could be granted the power to make final decisions should the Congress and the President disagree upon how to cut the budget to meet appropriate levels. See Bowsher, 478 U.S. at 717-18, 720.

183. One might argue that the ALJ is insulated from political pressures. That, however, does not answer the question of relative influence. As I have argued above, there is no question that relatively there are more political influences on an ALJ than on an Article III court-and that is the appropriate risk assessment here. See supra note 106 (describing the potential influences of a President on so-called independent agents). That the risk may be minimal goes to its weight, not its character.

184. The Court decided, ultimately, that the arrangement should stand because it found this incentive to be relatively weak and the corresponding protections strong. The Schor Court relied, for example, on the fact that the complaining party had voluntarily proceeded before an administrative tribunal, see 478 U.S. at 849-50, that the ALJ's orders were only enforceable through Article III courts, see id. at 852, and that the ALJ's legal determinations were subject to de novo review, see id. This reasoning makes little sense as an answer to the functional question: none of these factors changes the fact that the ALJ is in fact performing the function of adjudication. Each of these factors, however, lessens the likelihood of, and serves as a protection against, a politicized ALJ decision.

185. The real problem Bowsher presents is whether the President may agree to anticipatorily alienate the veto. The Budget Act at issue in Bowsher was, in effect, an ex ante agreement be- 
politicized offices (Congress and the President) to one of the least politicized, the "independent" Comptroller General. The danger in Schor was majoritarian, a risk that individual rights would be subject to political will; the danger in Bowsher was minoritarian, a risk that an important public decision would be made by a faceless bureaucrat. $^{186}$

\section{The Counterarguments}

Although I have answered them in part above, there are three objections and one question that I would like to face directly here. First, there is the objection that the text of the Constitution precludes the vertical approach; second, that history bars it; and, third, that vertical analysis raises difficult political questions ill-suited to judicial determination. Finally, there is the remaining question about how this approach fits into the existing academic controversy between formalists and functionalists.

First, as for the textual objection, let me emphasize that my argument is textual. I have relied upon the text that creates the relationships of citizens to state and, through these relationships, between departments. ${ }^{187}$ To some, of course, this is not the right text because the only "real" text is the text of the Vesting Clauses. That position may be understandable given courts' and scholars' focus on constitutional interpretation. The words "legislative," "judicial," and "execu-

tween the President and the Congress to bar his exercise of the veto power over budget decisions without regard to what later conflicts might arise between the nation's interests and the Comptroller General's ultimate budget decision. By cutting the President out, Congress not only gave itself more power but also cut out a national constituency as the final "veto" decisionmaker (absent a supermajority). Few, I believe, would argue that the President and the Congress can agree to forego the President's veto. Once understood this way, Bowsher, like Morrison, raises issues far different from the question of "independent" officers and "removal," on which the Court focused. See Bowsher, 478 U.S. at 722-26.

186. This conclusion holds whether we believe the Comptroller General to be an agent of Congress, of the President, or somewhere in between. However the Comptroller General is characterized, the statute (as interpreted by the Court) would still leave the President without the veto power at the time of the Comptroller General's budget-setting decision. See supra note 185 (explaining how Bowsher raises risks beyond the mere "independence" of the Comptroller General). For a different argument that the categorization issue is irrelevant based on an "aggrandizement" rationale, see Greene, supra note 24, at 167; see also David Yassky, A TwoTiered Theory of Consolidation and Separation of Powers, 99 YALE L.J. 431, 447 (1989) (maintaining that the Comptroller General's status should have had no bearing on the result in Bowsher).

187. See, e.g., U.S. CONST. art. I, § 2, cl. 1 (providing for the election of the members of the House of Representatives); id. art. I, § 3, cl. $1 \&$ amend. XVII (providing for the election of Senators); $i d$. art. II, $\S 1$, cls. $2-3 \&$ amend. XII (providing for the election of the President). 
tive" seem far more capable of interpretation than the electoral and appointment provisions in Articles I, II, and III. Yet, it hardly seems right to conclude that since these provisions do not appear as if they need, or are conducive to, the kind of interpretation given to the Vesting Clauses, they are for that reason less textual or less firm a basis for a government. ${ }^{188}$ If this is right, our continued search for the final meaning of judicial, legislative, and executive may not have given us anything but an impoverished sense of the text, at least one that leaves out, in this case, anything that would actually create a working government.

Second, the historical objection is equally illuminating about the limits of reliance on modern functional ideals. ${ }^{189}$ That most histories of the separation of powers are written with the concept of function in mind $^{190}$ does not tell us whether function means to us what it meant during the eighteenth century or, perhaps more importantly, if its meaning was important at all. The more evidence we gather, the more we find that conventional functional mixtures that would be unthinkable today were tolerated in early American history. ${ }^{191}$ I have written elsewhere that the idea of function that appears in The Federalist $\mathrm{Pa}$ pers, for example, is far more influenced by political practices of the

188. In this sense, the vertical approach suggests some very interesting things about the contemporary focus on constitutional interpretation. For if that focus tends to push us toward terms in the Constitution that need interpretation, it may skew not only the questions but the answers that we give about our Constitution; indeed, our search for an interpretive theory may have led us to look only at the kind of text susceptible to interpretation.

189. Of course, many have attempted to locate historical aims of the separation of powers in places other than function. Indeed, they have written eloquently of the fear of factions, conflicts of interest, and the need for balance as well as efficiency. See, e.g., Flaherty, supra note 29, (considering balance); Sunstein, Constitutionalism, supra note 123, at 430-32 (discussing faction and efficiency); Verkuil, supra note 24 (addressing the rule of law). There are several problems with extrapolations from such concerns. First, they are often stated at such a level of generality that they pose little opportunity for analysis of concrete problems. See supra note 140 (discussing the concept of "accountability" as compatible with diametrically opposed structural arrangements). Second, these arguments are often disconnected from relevant political practice. See, e.g., Desan, supra note 33, at 1385 (emphasizing the importance of early political practices as important for understanding early structural arrangements); Nourse, supra note 10, passim (arguing that political practices tell us much about the Federalist's arguments on the separation of powers). Finally, and perhaps most importantly for my purposes, these theories all rely upon common assumptions about the nature of political power; they assume that shifting power is a matter of shifting ability to command rather than shifting political relationships. See infra Part IV.

190. See supra note 33 and accompanying text.

191. See Desan, supra note 33, at 1391-435 (focusing on the early history of the New York Assembly and its use of legislative adjudication). 
time than we moderns understand. ${ }^{192}$ Indeed, I believe that a strong argument can be made that Madison's key insight in terms of political structure married more traditional ideas of mixed government to the new republic's overlapping constituencies. ${ }^{193}$ If that is right, then, our modern idea may have caused us to focus too much on historical notions of function and too little on relevant political practice. At the very least, it supports a shift in our thinking so as to contemplate the role of constituency and political relationships in the separation of powers.

Third, the practical objection. There will be those who urge that courts cannot undertake the vertical approach. Leaving aside for the moment the fact that the vertical approach may actually describe the Supreme Courts' reasoning in a number of cases, ${ }^{194}$ let me treat the objection at its most general. It is believed by many that, since we cannot know the "end" of the separation of powers, courts should simply call these cases political questions and abstain from deciding them. ${ }^{195}$ The vertical approach makes clear, however, that the question of judicial review cannot be decided as if courts were taking the "view from nowhere." 196 To believe, as many do, that the Court can stay out of politics by ignoring separation of powers challenges is not to stay out of politics; rather, it is to affirm a particular kind of politics. ${ }^{197}$ The Court's refusal to intervene is a claim that the political branches have the final word on constitutional structure ${ }^{198}$ and that

\footnotetext{
192. See Nourse, supra note 10 , at 453-63.

193. See id. at 481-82.
}

194. See supra notes 10, 114 (discussing Justice Kennedy's specific reference to "vertical" concerns); supra text accompanying notes 174-84 (discussing how a vertical approach reconciles the Supreme Court's analyses in Bowsher and Schor).

195. See, e.g., CHOPER, supra note 34, at 263-379 (arguing that separation of powers claims should be nonjusticiable); Tushnet, supra note 27, at 596-97 (questioning whether judges have the knowledge to understand politics or to evaluate claims of shifting power).

196. See Thomas Nagel, The View From Nowhere (1986) (addressing the problem of a person inside the world attempting to take an objective view of the world of which they are a part).

197. See Sunstein, Constitutionalism, supra note 123, at 495 (arguing that "[a]cquiescence by one branch to a redistribution of national powers may not prevent-indeed it may increase- - the danger that the new arrangement will jeopardize some of the purposes that underlie the constitutional structure").

198. I suspect that the commitment to this position (borrowed from other debates about judicial review) is likely to be skin deep. Would the realists really support judicial silence, or deferential review, if the President and the Congress agreed that the President had no veto on such matters as race discrimination or abortion? If there is any lesson that we have learned from Morrison, it is that what may seem politically wise, impartial, and sound in the short term may end up appearing quite different in the long term. 
the courts are simply constitutional bystanders. If we are to have a constitution, the political departments cannot simply choose a new structure when the majority sees fit to change it. ${ }^{199}$ I would add that, if we are to have courts, we cannot believe that they do not perform a role in the great institutional debates or that their role as political outsiders does not contain both risks ${ }^{200}$ and benefits. Law's voice counts, too, in a republic-it counts, at the very least, as the voice of caution, articulating for us the risks of what may seem at the moment a wise and worthwhile product of popular will. ${ }^{201}$

To say that this invites courts into a political quagmire both overstates the difficulty of the inquiry and understates the degree to which the Court's "transcendentalist" view is already a political mess. To see the risks of elitism and oppression, to which I have adverted, requires no Master's degree in political science or a penchant for reading studies on congressional voting behavior. Albeit expressed somewhat differently, the risks that I have identified are quite standard concepts in the general literature of constitutional law and theory, even if they are not always seen together. ${ }^{202}$ In the end, however, the best claim I have for the vertical approach is that it produces accounts that make more sense of the real constitutive risks of shifting power than an approach based solely on the concept of function.

199. I make no claim here to provide a full theory of judicial review of separation of powers questions. Indeed, I think that the question may be a difficult one, concerning whether the Court is really the best institution to decide certain kinds of structural disputes. I assume, as a pragmatic matter, however, that the Supreme Court will continue to exercise review in some structural cases.

200. What I mean by this is that the very act of deciding these cases, of engaging in judicial intervention, may itself be an accretion of power that deserves scrutiny. Indeed, if there is any truth to the account in Part III, it suggests that the Court has failed too often to consider its own role in separation of powers controversies.

201. As a practical matter, most separation of powers disputes are resolved on the political playing field-an everyday matter in Washington. See LOUIS FISHER, ConstituTIONAL CONFLiCts BetweEn CONGRESS AND THE PREsident 299 (4th ed. 1997) (noting that "it is not surprising that the meaning of separation of powers has for the most part developed outside the courts .... [in] accommodations worked out by legislative and executive officials"). This is not, however, an argument against judicial intervention; it simply reflects the general truth that most disputes are never resolved by adjudication. Life, and separation of powers disputes, most often take place in the shadow of the law; however, at some point the law must be expounded in order to cast its shadow.

202. See Ely, supra note 138, at 68 (discussing political philosophies that embrace elitism); SANDEL, supra note 147, at 128 (identifying the Framers' fears of an "excess of democracy"). But see Komesar, Job for Judges, supra note 53, at 668-72 (examining both kinds of political malfunction). 
Finally, where does a vertical approach fit into current debates on formalism and functionalism? To the extent that it looks for reasons to decide separation of powers controversies, it clearly belongs in the functionalist camp. Unlike many functionalist approaches, however, it does not give content to the idea of function by seeking agreement upon a final picture of the departments or constitutional structure. Rather, it posits an end in the expression of popular will. This aims to be not only a more realistic approach but also one that does not depend upon the political majorities of the moment. Rather, it is realist in the sense that functional argument, I believe, was intended to be-an argument that sees in abstraction the source of oppression and confusion and posits a way of reinventing existing thought patterns by reenvisioning the relations embodied in law. It is realist in the sense that Felix Cohen imagined functionalism as critique ${ }^{203}$ it is functionalist in the sense of Wesley Hohfeld and John Dewey, who emphasized the use of relational understandings to rethink entrenched concepts. ${ }^{204}$

\section{THE IDEA OF POWER AND THE COURTS' ROLE IN SEPARATION OF POWERS CASES}

Decades ago, one of the century's most distinguished constitutional scholars, Professor Charles Black, implored us to see that the Constitution creates a set of political relationships. ${ }^{205}$ Surprisingly little of that understanding, however, seems to have informed contemporary debates about the separation of powers in the Supreme Court, in the law reviews, or among scholars. In part, this may be due to the fact that Professor Black focused on particularly difficult relationships. ${ }^{206}$ More likely, however, such an understanding has been disregarded because lawyers tend to see some constitutional relationships-particularly the ones I have identified here-as matters of politics, not law. ${ }^{207}$ The resulting misunderstanding, a very important

\footnotetext{
203. See supra note 28 .

204. See John Dewey, How We ThINk 134 (1991) (recommending that meaning may be more precise if we seek not to describe static qualities but, instead, "the way in which certain things are causally related to other things, i.e. ... a relation"); Wesley N. Hohfeld, Some Fundamental Legal Conceptions as Applied in Judicial Reasoning, 23 YALE L.J. 16, 20-22 (1913) (offering a vision of correlative understandings to understand legal terms of art).

205. See BLACK, supra note 37, at 3-32.

206. See, e.g., id. at 39-66 (making arguments based on the relationships of state to nation and citizen to state).

207. What has been borrowed from Professor Black's work is not the idea of political rela-
} 
one, is that somehow the political relationships created by the Constitution are less certain or evident, and even less textual, than the "real" constitutional law found in particular articles and clauses. ${ }^{208}$

The separation of powers debate is, in the end, a debate as much about the structure of our government as about an idea of law and political power. To a lawyer, political power is created in the image of law. Power is not the power to speak on behalf of others, as political theorists tell us; instead, power is the power to command legitimately. ${ }^{209}$ Shifts in power do not shift constituencies or political voice, but they shift the legal authority to do something. This view, when applied to the separation of powers, has kept our gaze on rather lawyerly questions. Scholars are obsessed with answering questions about departmental hierarchy ${ }^{210}$ and the best interpretation of the terms of the departments' grants of authority, the Vesting Clauses. ${ }^{211}$ Even functionalists, who aim toward a more critical stance, borrow this lawyerly assumption. They simply wish to soften its implications.

The problem for this lawyerly ideal is the one with which I began this Article: it does very little actually to create a government. Neither the Vesting Clauses nor enumerated powers authorize the vote or create constituencies. As a result, they cannot create the kind of relationships that lawyers describe somewhat disdainfully as "political" power. Law's vision of power as authority or command may be necessary to understand governmental structure, but it is not suffi-

tionship but the idea of structural argument. That, too, however, has an uncertain legacy. While many assert that they are making "structural" arguments, there appear to be wide differences about what, precisely, structural argument is and what it supports. Compare Calabresi \& Rhodes, supra note 31, at 1212 (using "structure" to mean an argument that compares the precise language of the Vesting Clauses and one that supports a unitary executive), with A. Michael Froomkin, The Imperial Presidency's New Vestments, 88 Nw. U. L. REV. 1346 (1994) (rejecting Calabresi and Rhodes's argument as not "structural" enough).

208. Professor Black clearly sought to move beyond a clause-bound textualism. See BLACK, supra note 37. Yet, he also recognized that "the structure and relations concerned are themselves created by the text." Id. at 31 .

209. The notion of law as the command of the sovereign is, of course, a staple of much jurisprudential thought of ancient and modern lineage. See J.M. Kelly, A SHORT History of WESTERN LEGAL THEORY 289 (1992) ("We have seen virtually throughout the history of Western legal thought that, when law is defined, it receives a definition in which the imperative element, in other words the element of command, is central."). But cf. H.L.A. HART, THE CONCEPT OF LAW 20-25 (1994) (arguing that there are many rules in a system we call "law" that do not meet the strict Austinian model of law as a command supported by sanction).

210. The debates about the unitary executive provide an example of this obsession. See supra note 163 and accompanying text.

211. See, e.g., Calabresi \& Rhodes, supra note 31, passim (analyzing the Vesting Clauses at length). 
cient. The Constitution not only limits the exercise of political power but also creates political power. ${ }^{212}$ In a sense, we should know this. The Founders knew it: Madison understood that political order depends upon channeling public opinion. ${ }^{213}$ The moderns know it: political philosophers of various stripes have argued that power is public voice and relationship..$^{214}$ Indeed, in an age of resurgent interest in republicanism, ${ }^{215}$ it seems particularly odd that lawyers would continue to invest unreflectively in the notion that political power is only function or authority. Surely, to believe that power is decreed from somewhere on high, transcending public voice, is antithetical to the notion that "we the people" constitute our government.

The great danger here is not that the Supreme Court will make the wrong decision. We have survived two hundred years of structural controversy, some true crises, and more than a few difficult judicial decisions. But it is tempting to wonder whether we would be better off if the Court did not base its decisions on a view of the world in its own image. Like most institutions, courts have a tendency toward institutional self-regard, and this affects the ways in which they think about concepts. ${ }^{216}$ Function, as law, sees the world of political power in the image of law, and it sustains the courts' idea of their own legitimacy by placing in their hands the rule of law. But this kind of self-regard, however important in some respects, also poses risks. For

212. As Richard Parker has tellingly written, almost all constitutional scholarship is antipopulist in the sense that it is hostile to the release of political energy. See RICHARD D. Parker, "Here The People Rule": A Constitutional Populist Manifesto 65 (1994) ("In the minds and hearts of most American constitutional lawyers, an Anti-Populist sensibility appears to predominate now.").

213. See Michael Schudson, The Good Citizen: A History of AmericAn Civic Life 89 (1998) (arguing that Madison hoped and expected "that public opinion would find its voice in and through the formal institutions of government" and noting his belief that "[p]ublic opinion was as much something that government would make possible as it was the instrument to make a government").

214. See ARENDT, supra note 10, at 44 ("When we say of somebody that he is 'in power' we actually refer to his being empowered by a certain number of people to act in their name."); HAMPTON, supra note 10, at 112-14.

215. See, e.g., Frank I. Michelman, Law's Republic, 97 YALE L.J. 1493, 1495 (1988) (contending that "republican constitutional thought is not indissolubly tied to . . static, parochial, or coercive communitarianism"); Frank I. Michelman, The Supreme Court 1985 Term-Foreword: Traces of Self-Government, 100 HARV. L. REV. 4, 73 (1986) (arguing that a court's lawmaking role must "sound in virtual representation"); Cass R. Sunstein, Beyond the Republican Revival, 97 YALE L.J. 1539 (1988) (discussing republican thought and describing the implications of republicanism).

216. For an extended argument, see Victoria Nourse, Making Constitutional Doctrine in a Realist Age, 145 U. PA. L. REV. 1401 (1997). 
in such a world, it is possible to sever the people from their Constitution, to believe, as the Supreme Court so recently said, that it is possible to have a government in which a man simply "happens" to be President. $^{217}$ "[A] legal order cannot in the long run be true to itself and at the same time be better than the values or vision of its beneficiaries. ${ }^{, 218}$ In the end, a constitution disembodied is no constitution at all.

217. Clinton v. Jones, 520 U.S. 681, 701 (1997).

218. HURST, supra note 12, at 5. 